\title{
Recovery of noble metals from spent catalysts: a review
}

\author{
Sai Krishna Padamata ${ }^{1}$, Andrey S. Yasinskiy ${ }^{1 *}$, Peter V. Polyakov ${ }^{1}$, Evgeny A. Pavlov ${ }^{2}$, Dmitriy \\ $Y$ u. Varyukhin ${ }^{1}$ \\ ${ }^{1}$ School of non-ferrous metals and materials science, Siberian federal university, Krasnoyarsk, \\ Russia 660025 \\ ${ }^{2}$ JSC “Krastsvetmet”, Krasnoyarsk, Russia 660027 \\ * corresponding author \\ saikrishnapadamata17@gmail.com \\ * ayasinskiykrsk@gmail.com \\ p.v.polyakov@mail.ru \\ doc50@mail.ru \\ dimka1933@yandex.ru
}

\begin{abstract}
During several past decades, plenty of technologies for platinum group metals (PGM) and rhenium $(\mathrm{Re})$ recovery from electronic wastes and spent catalysts have been developed and published. The reasons for the rising interest in this area are:

$\square$ The abundance of these elements in the earth's crust is less than $10^{-3} \mathrm{ppm}(\sim 6.6$ $10^{4} \mathrm{t}$ all over the world);

$\square$ global demand for PGMs is over $590 \mathrm{t}$;

$\square$ electronics and catalysts industry consumes over $90 \%$ of precious metals (about $65 \%$ of $\mathrm{Pd}, 45 \%$ of $\mathrm{Pt}$ and $84 \%$ of $\mathrm{Rh}$ are consumed in catalytic converters);

$\square$ properties of PGMs and Re (resistance towards corrosion and oxidation, high melting temperatures, electrical conductivity, and catalytic activity) are of great commercial interest.

Even though several comprehensive reviews on the recovery of precious metals from spent catalysts have been recently published, several developments were out of the attention of the scientific community. The reviews divide the technologies into hydro- and pyrometallurgical ones. However, the variety of different approaches requires a more detailed classification. This article is an overview of the recently reported works and the comparison of different technologies in terms of extraction efficiency, environmental friendliness, and capital and operational expenditures. The new electrochemical method, which is now under development, is also presented.
\end{abstract}

Keywords: spent catalysts processing, platinum group metals, hydrometallurgical process, pyrometallurgical process, electrochemical process, magnetic separation

\section{Introduction}

Platinum group metals incorporate six noble metals namely, platinum $(\mathrm{Pt})$, palladium $(\mathrm{Pd})$, iridium $(\mathrm{Ir})$, osmium $(\mathrm{Os})$, rhodium $(\mathrm{Rh})$, and ruthenium $(\mathrm{Ru})$. All the metals from this group possess more or less identical physical and chemical properties. PGMs are chemically inert, highly resistant against corrosion, electrically and thermally stable, shows high mechanical strength [1-3]. The properties possessed by them are highly desirable and over $90 \%$ of overall PGMs are used by electrical and catalyst industries. PGMs are limited natural resources with only 66000 tons available across the earth. Only $2-10 \mathrm{~g} / \mathrm{t}$ of PGM content is present in its natural ores. The recovery of the PGM as a co-product or a by-product depends upon their percentage in the ore. Recent advancements in the technologies for the extraction and recovery of PGM have 
enhanced its application in the chemical industry, oil refining, medical practices, vehicle and equipment construction, jewelry making, etc. $[4,5]$.

Production of $73 \%$ of primary PGMs in the world is associated with the Bushveld Complex of South Africa, while the rest of the PGMs reserves are mainly concentrated in Russia, Zimbabwe, the United States, and Canada [6]. The PGM ores are mainly in the form of sulfide and arsenide materials like $\mathrm{PtAs}_{2}, \mathrm{Pt}(\mathrm{AsS})_{2}, \mathrm{PtS},(\mathrm{Pt}, \mathrm{Pd}) \mathrm{S},(\mathrm{Pt}, \mathrm{Pd}, \mathrm{Ni}) \mathrm{S}, \mathrm{Pd}_{3} \mathrm{Sb}$ and $\mathrm{RuS}_{2}$ along with elemental ruthenium [7]. Fernandez [8] presented comprehensive data related to the amounts of PGMs in different forms. PGMs are recovered from the high-grade concentration ores (200 to $2000 \mathrm{~g} / \mathrm{t}$ of PGM and 0.3 to $2.5 \% \mathrm{Cr}_{2} \mathrm{O}_{3}$ ) by matte-smelting-refining technique. Initially, the PGM ores are crushed and ball-milled to make them fine particles. This ore in the form of particles is treated in the gravity separators and transferred to the flotation cells to produce a sulfide-rich PGM concentrate, where reagents like dithiophosphate and xanthate collectors are used for flotation process at $\mathrm{pH}$ of 7.5 to 9 [9]. Smelting is performed on the sulfide-rich PGM concentrates to remove feldspar, plagioclase, pyroxene, and biotite gangue materials. The matte is treated in converters where the slag containing $\mathrm{SO}_{2}, \mathrm{FeO}$ is removed. The converter matte is transferred to a base metal refinery where $\mathrm{Cu}, \mathrm{Ni}$, and other metals are removed. The PGM concentrate with more than 65\% PGM is refined in precious metal refinery and high-quality PGMs are recovered (see figure 1).

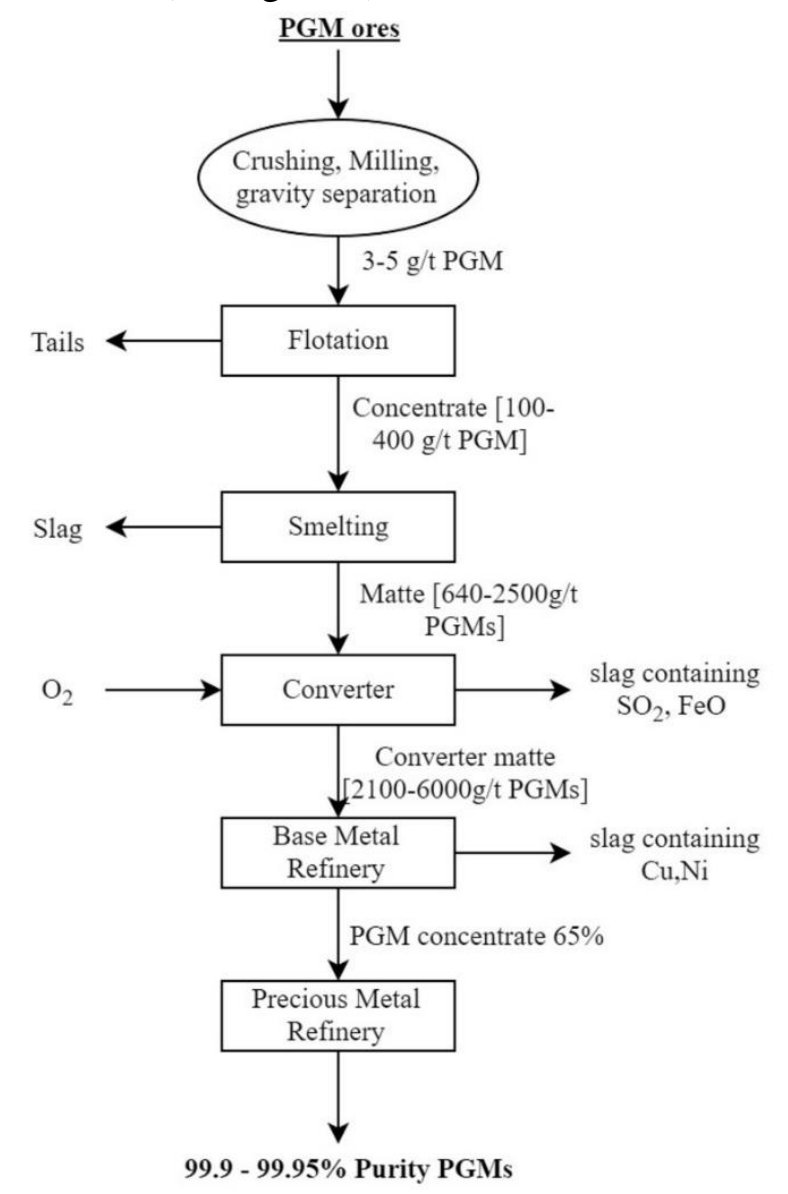

Figure 1. PFD of the PGM extraction from ores

The demand for PGMs is increasing due to its various applications in the industries. 




Figure 2. The total supply and demand for PGMs in 2019 (in tons) [11]. 1- Total supply, 2- Gross demand, 3- Total recycling, 4- Total net demand, 5-Movements in stocks. Note: ${ }^{*}$ - No available data

Spent catalyst is one of the sources for the PGM recovery. The catalyst used in the refining and petrochemical industries constitutes of $\mathrm{Al}_{2} \mathrm{O}_{3}$-based carrier with $0.05-1 \%$ of noble metals (PGM and rhenium) as the active components. The catalyst loses its catalytic properties after a certain time ( 3 to 5 years), technology to regenerate and reactivate the metal fouled catalyst is not available at present and are discarded as the solid wastes [12,13]. The spent refinery catalyst amounts only $4 \%$ of the total refinery wastes but still is considered to be the most hazardous waste generated in the petroleum industry [14, 15].

The catalyst industry heavily depends on PGMs, which act as active components. The oilrefining, automobile emission purification, chemical engineering industries are the main consumers of PGMs in the form of the catalyst [16]. Immense research has been conducted by researchers to replace the PGMs with fewer abandon materials but no significant results were attained. About $45 \%$ of platinum (99.82 tons), $65 \%$ of palladium (186.5 tons) and $84 \%$ of rhodium (24.07 tons) were used in catalytic converters in the year 2018. The recycling of PGMs from the spent catalyst is difficult as it is used for different purposes and varying proportions of PGMs from $200 \mathrm{ppm}$ to $100 \%$ in an entire catalyst material. Table 1 elaborates on the information of catalysts used in automobiles and chemical industries.

Table 1. PGMs used for applications in industries [17].

\begin{tabular}{|c|c|c|c|c|c|}
\hline $\begin{array}{l}\text { Application } \\
\text { areas }\end{array}$ & Application & Catalyst type support & PGMs & PGMs loading/ \% & $\begin{array}{c}\text { Life span } \\
\text { (year) }\end{array}$ \\
\hline Fine chemicals & $\begin{array}{l}\text { Hydrogenation } \\
\text { Oxidation } \\
\text { Debenzylation }\end{array}$ & Activated carbon & $\begin{array}{l}\mathrm{Pd} ; \mathrm{Pd} / \mathrm{Pt} \mathrm{Ru} ; \\
\mathrm{Rh} ; \mathrm{Ir}\end{array}$ & $0.5-10$ & $0.1-0.5$ \\
\hline Automotive & $\begin{array}{l}\text { Diesel particulate } \\
\text { filter }\end{array}$ & $\begin{array}{l}\text { Cordierite monolith } \\
\text { ceramic pellets } \\
\text { Metallic monolith } \\
\text { SiC or cordierite }\end{array}$ & $\begin{array}{l}\mathrm{Pt} / \mathrm{Rh} \mathrm{Pt}-\mathrm{Pd}- \\
\mathrm{Rh} \mathrm{Pt}\end{array}$ & $0.1-0.5$ & $>10$ \\
\hline Oil-refining & $\begin{array}{l}\text { Reforming } \\
\text { Isomerization } \\
\text { Hydrocracking } \\
\text { Gas to liquid }\end{array}$ & $\begin{array}{l}\mathrm{Al}_{2} \mathrm{O}_{3} \\
\mathrm{Al}_{2} \mathrm{O}_{3} \text {, zeolites } \\
\mathrm{SiO}_{2}, \text { zeolites } \\
\mathrm{Al}_{2} \mathrm{O}_{3}, \mathrm{SiO}_{2}, \mathrm{TiO}_{2}\end{array}$ & $\begin{array}{l}\mathrm{Pt} ; \mathrm{Pt} / \mathrm{Re}, \mathrm{Pt} / \mathrm{Ir} \\
\mathrm{Pt} ; \mathrm{Pt} / \mathrm{Pd} \\
\mathrm{Pd} ; \mathrm{Pt} \\
\mathrm{Co}+(\mathrm{Pt} ; \quad \mathrm{Pd} ; \\
\mathrm{Ru} ; \mathrm{Re})\end{array}$ & $0.02-1$ & $1-12$ \\
\hline $\begin{array}{l}\text { Chemical } \\
\text { engineering }\end{array}$ & $\begin{array}{l}\text { Nitric acid } \\
\mathrm{H}_{2} \mathrm{O}_{2} \\
\text { PTA* }^{*} \\
\mathrm{HCN}^{*} \\
\text { VAM* }^{*} \\
\text { KAAP* }^{*}\end{array}$ & $\begin{array}{l}\text { Gauzes } \\
\text { Powder (black) } \\
\text { Carbon granules } \\
\mathrm{Al}_{2} \mathrm{O}_{3} \text { or gauzes } \\
\mathrm{Al}_{2} \mathrm{O}_{3}, \mathrm{SiO}_{2} \\
\text { Activated carbon }\end{array}$ & $\begin{array}{l}\mathrm{Pd} \\
\mathrm{Pd} \\
\mathrm{Pd} \\
\mathrm{Pt} ; \mathrm{Pt} / \mathrm{Rh} \\
\mathrm{Pd} / \mathrm{Au} \\
\mathrm{Ru}\end{array}$ & $\begin{array}{l}100 \\
100 \\
0.5 \\
0.1 ; 100 \\
1-2\end{array}$ & $\begin{array}{l}0.5 \\
1 \\
0.5-1 \\
0.2-1 \\
4\end{array}$ \\
\hline Homogeneous & $\begin{array}{l}\text { Oxo Alcohols } \\
\text { Acetic acid }\end{array}$ & Homogeneous & $\begin{array}{l}\mathrm{Rh} \\
\mathrm{Rh} ; \mathrm{Ir} / \mathrm{Ru}\end{array}$ & $\begin{array}{l}100-500 \mathrm{ppm} \text { in the } \\
\text { process solution }\end{array}$ & $1-5$ \\
\hline
\end{tabular}


Note*: PTA - Purified terephthalic acid, HCN - Hydrogen cyanide, VAM - Vinyl Acetate Monomer, KAAP - KBR Advanced Ammonia Process.

Effective recovery of PGMs and extraction from spent catalysts are environmentally and economically desirable. Three factors are influencing the recyclability of spent catalysts: (1) the composition of the spent catalyst, (2) the intrinsic metal value, and (3) the associated lifecycle structure and the application segment, including the turnaround speed (catalyst life), recycling chain and business model.

In this paper, the methods implemented to recover the PGMs from the spent catalyst are discussed. The advantages and disadvantages associated with the various recycling methods will be mentioned. This topic is particularly important, as in the future the industries will be relying on recycling processes to obtain PGMs. Recycling should be efficient and environmentally friendly. The recovery of PGMs from the spent catalyst is important because of:

$\square$ simple catalyst composition with carriers being $\mathrm{Al}_{2} \mathrm{O}_{3}$, activated carbon, cordierite, and so on;

$\square$ high PGM proportion of about several kilograms per ton.

Therefore, the recovery of PGMs from the spent catalysts should be economically advantageous, small scale, simple, and environmentally friendly process. Techniques like noncyanide leaching, smelting in the furnace, mild leaching, and physical separation pre-treatment cause less pollution and have been developed in the last two decades. Nevertheless, even with many advantages, they show negative effects on the environment and recovery process $[18,19]$.

\section{Techniques used for the PGMs recovery from spent catalysts}

The supply of spent catalysts to the recycling process is a crucial step as it is a decisive factor in the recovery of the PGMs. The spent catalyst should undergo (1) dismantling, (2) size reduction, and (3) physical separation before the start of the main process [20]. The selection of the recycling technique mainly depends on three factors: (1) type of catalyst's supporter, (2) PGM (loading) content, and (3) presence of other base metals. Finally, recycling of spent catalyst to extract PGMs can be distinguished into five basic steps: sampling/homogenization, preconcentration, dissolution, enrichment, and purification. Several recovery techniques have been introduced for the past 20 years and few of them are already employed at the industrial level [21, $22]$. The below techniques are a few of them, which will be discussed briefly.

\subsection{Hydrometallurgy}

In the hydrometallurgical process, the spent catalysts are dissolved in the aqua regia, cyanide, or strong acids like $\mathrm{HNO}_{3}, \mathrm{HCl}$, and $\mathrm{H}_{2} \mathrm{SO}_{4}$. The leaching efficiency is enhanced by adding oxidizing agents like $\mathrm{O}_{2}, \mathrm{H}_{2} \mathrm{O}_{2}, \mathrm{Cl}_{2}$, and $\mathrm{I}_{2}$. Before the leaching process, the PGMs should be reduced to the metallic state as they turn into the inert state due to the sulfuration or oxidation. In this process, $\mathrm{Pd}$ is leached easily while $\mathrm{Rh}$ cannot be leached for more than $90 \%$. Cyanide leaching is a more efficient recovery process but as this method is performed at high temperatures, cyanide is highly toxic.

\subsubsection{Hydrochloric acid + oxidant system leaching}

In this process, $\mathrm{PGMs}$ are leached in $\mathrm{HCl}$ medium with oxidizing agents such as $\mathrm{Cl}_{2}$, $\mathrm{H}_{2} \mathrm{O}_{2}, \mathrm{HNO}_{3}$, and $\mathrm{NaClO}_{3}$, etc. [23-25]. The PGMs form the soluble chloro-complexes when reacted with $\mathrm{HCL}$ and the oxidizing agent, according to the following reactions:

$$
\begin{aligned}
& 3 \mathrm{Pd}+12 \mathrm{HCl}+2 \mathrm{HNO}_{3} \rightarrow 3\left[\mathrm{PdCl}_{4}\right]^{2-}+6 \mathrm{H}^{+}+2 \mathrm{NO}+4 \mathrm{H}_{2} \mathrm{O} \\
& 3 \mathrm{Pt}+18 \mathrm{HCl}+4 \mathrm{HNO}_{3} \rightarrow 3\left[\mathrm{PtCl}_{6}\right]^{2-}+6 \mathrm{H}^{+}+4 \mathrm{NO}+8 \mathrm{H}_{2} \mathrm{O}
\end{aligned}
$$




$$
\mathrm{Rh}+6 \mathrm{HCl}+\mathrm{HNO}_{3} \rightarrow\left[\mathrm{RhCl}_{6}\right]^{3-}+3 \mathrm{H}^{+}+\mathrm{NO}+2 \mathrm{H}_{2} \mathrm{O}
$$

The above reactions (1) - (3) show the formation of the complex PGM ions when $\mathrm{HNO}_{3}$ oxidizing agent is used and similar ions are obtained when $\mathrm{Cl}_{2}$ is used as an oxidizing agent and can be seen from the reactions [26]:

$$
\begin{aligned}
\mathrm{Pd}+2 \mathrm{HCl}+\mathrm{Cl}_{2} & \rightarrow\left[\mathrm{PdCl}_{4}\right]^{2-}+2 \mathrm{H}^{+} \\
\mathrm{Pt}+2 \mathrm{HCl}+2 \mathrm{Cl}_{2} & \rightarrow\left[\mathrm{PtCl}_{6}\right]^{2-}+2 \mathrm{H}^{+} \\
2 \mathrm{Rh}+6 \mathrm{HCl}+3 \mathrm{Cl}_{2} & \rightarrow 2\left[\mathrm{RhCl}_{6}\right]^{3-}+6 \mathrm{H}^{+}
\end{aligned}
$$

Decomposition of Hydrochloric acid when oxidizing agents are added occurs according to the reactions (7)-(10). Obtained $\mathrm{Cl}_{2}$ react with the PGMs, leading to the formation of soluble PGM chloro-complexes and reduces the processing time.

$$
\begin{aligned}
2 \mathrm{HCl}+\mathrm{H}_{2} \mathrm{O}_{2} & \rightarrow \mathrm{Cl}_{2}+2 \mathrm{H}_{2} \mathrm{O} \\
12 \mathrm{HCl}+2 \mathrm{NaClO}_{3} & \rightarrow 2 \mathrm{NaCl}+6 \mathrm{Cl}_{2}+6 \mathrm{H}_{2} \mathrm{O} \\
3 \mathrm{HCl}+\mathrm{HNO}_{3} & \rightarrow \mathrm{NOCl}+\mathrm{Cl}_{2}+2 \mathrm{H}_{2} \mathrm{O} \\
2 \mathrm{HCl}+\mathrm{NaClO} & \rightarrow 2 \mathrm{NaCl}+\mathrm{Cl}_{2}+\mathrm{H}_{2} \mathrm{O}
\end{aligned}
$$

The extraction of PGMs highly depends upon its dissolution and the formation of chloride complexes, which are stable at $\mathrm{pH}<1$, whereas at high $\mathrm{pH}$ values, the chloride complexes are hydrolyzed forming hydroxy complexes [27]. To avoid slow leaching the pretreatment should be performed on the PGMs as their surface is covered with many organic substances. Processes such as pre-leaching, reduction roasting, and oxidation roasting are suggested [28].

Shams et al. [29] conducted a study where $280 \mathrm{~g}$ of spent dehydrogenation catalyst was decoked at $400-450{ }^{\circ} \mathrm{C}$ and then crushed to a particular size required. Leaching of the particles was then made with a mixture of $3850 \mathrm{gm}$ of concentrated hydrochloric acid $\left(5 \mathrm{~mol} . \mathrm{L}^{-1}\right)$ and nitric acid $\left(\mathrm{HNO}_{3}-0.2 \mathrm{vol} . \%\right)$ solution which is used as a leaching agent in a $5000 \mathrm{cc}$ container. The recovery process is followed by the ion exchange of the metallic complexes with the help of strong base ion exchange resin (AMBERTJET $4200 \mathrm{Cl}$, industrial grade). The replacement of chloride anion by hydroxyl group ion to treat the strong basic anionic resin by using a sodium hydroxide solution. It was observed that the PGM recovery increased with the increase of $\mathrm{HCl}$ concentration in the solution. At 9 mol. $\mathrm{L}^{-1} \mathrm{HCl}$ concentration, the results were excellent. This process is temperature-sensitive with the best extraction obtained at $100{ }^{\circ} \mathrm{C}$. This states that the recovery of PGMs from spent catalyst while using $\mathrm{HCl}$ requires less leaching severity reactions. The process is also not time-efficient (slow) as studies show that after 24 hours of leaching, no further recovery of PGMs was possible. Angelidis et al. [30] developed a laboratory-scale hydrometallurgical process for the recovery of $\mathrm{Pt}$ and $\mathrm{Rh}$ from the spent catalyst. The process constitutes oxidation leaching $\left(\mathrm{NaClO}, \mathrm{HCL}\right.$, and $\left.\mathrm{AlCl}_{3}\right)$, reduction leaching $\left(\mathrm{H}_{2} \mathrm{SO}_{4}\right.$ and $\mathrm{N}_{2} \mathrm{H}_{6} \mathrm{SO}_{4}$ ) and final leaching with $\mathrm{HCl}$ followed by the neutralization of the metal. About $94 \%$ of $\mathrm{Pt}$ and $89 \%$ of $\mathrm{Rh}$ were recovered. Similar results were obtained in a process where $\mathrm{CeO}_{2}$ was used as an additive to increase the recovery rate of the PGMs, although while separating the PGMs from the residue, a significant amount of Ce was leached along with the PGMs [31].

Matjie et al. [32] reported that the spent catalyst was first calcined at around $800{ }^{\circ} \mathrm{C}$ to remove the wax present in it to heighten the extraction efficiency during the leaching process. 
The calcined spent catalyst containing $7.67 \%$ of Pt was then dissolved in $1000 \mathrm{ml}$ aqua regia $\left(3 \mathrm{HCl}: 1 \mathrm{HNO}_{3}\right)$ at $90{ }^{\circ} \mathrm{C}$ for 240 mins at atmospheric pressure to attain chloroplatinic acid species. Then filtration is carried out to separate the metal from the insoluble aqua regia residue. The XRD was performed on aqua regia residue to find the Pt content and only traces of Pt were seen, stating that almost all the Pt present in the calcined catalyst was dissolved (see figure 3 ).

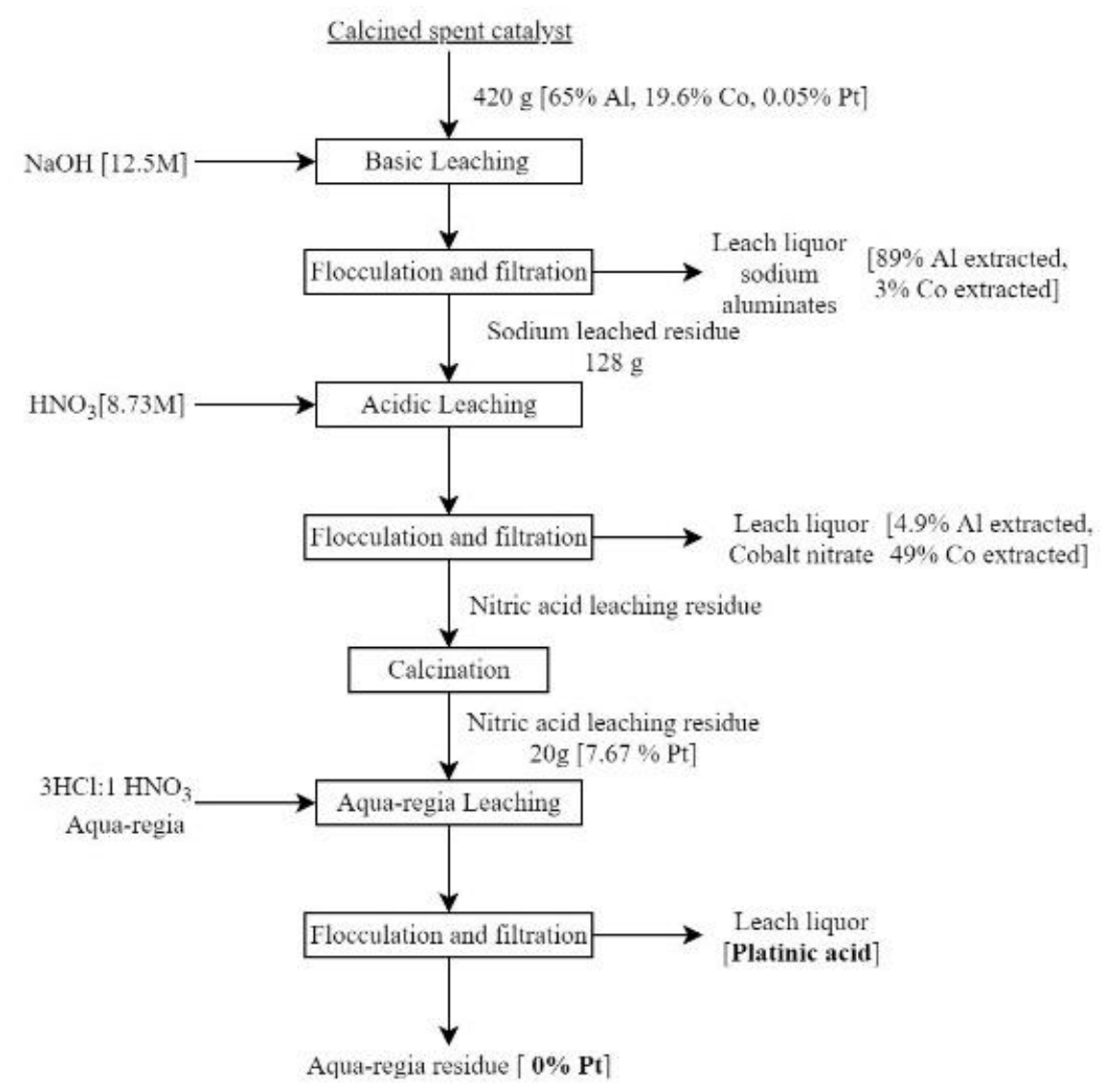

Figure 3. PFD of aqua-regia leaching process [32] 
The $\mathrm{HCl}$ leaching was performed on spent activated carbon-supported Pd catalyst with hydrogen peroxide as a leaching agent for the Pd recovery. The leaching process was carried out for 90 mins at $90{ }^{\circ} \mathrm{C}$. A maximum leaching rate of $99 \%$ was attained for $\mathrm{Pd}$ when the solution mixture contained 10 vol. $\% \mathrm{HCl}$ and 5 vol. $\% \mathrm{H}_{2} \mathrm{O}_{2}$. The increase in temperature and time improved leaching efficiency. The optimum conditions to recover Pd were when the solution with 10 vol. $\% \mathrm{HCl}$ and 5 vol. $\% \mathrm{H}_{2} \mathrm{O}_{2}$ was used at $90{ }^{\circ} \mathrm{C}$ for 180 mins [33]. Paiva et al. [34] investigated the hydrometallurgical process to extract Pd from the spent alumina catalyst, where the $\mathrm{HCl}$ solution is used for the leaching. The main task of this investigation was to achieve a promising recovery of $\mathrm{Pd}$ with minimal $\mathrm{Al}$ contamination. $\mathrm{H}_{2} \mathrm{O}_{2}$ was used as an oxidizing agent, which improved the Pd leaching in $\mathrm{HCl}$ to above $90 \%$, the ideal conditions were being (2.0 mol. $\left.\mathrm{L}^{-1}\right) \mathrm{HCl},\left(1.0 \mathrm{~mol}\right.$. $\left.\mathrm{L}^{-1}\right) \mathrm{H}_{2} \mathrm{O}_{2}$ at $25^{\circ} \mathrm{C}$ and reaction time is $10-15$ mins. The $\mathrm{Al}$ contamination can be decreased by reducing the acidity, a mixture of $\mathrm{HCl}, \mathrm{H}_{2} \mathrm{O}_{2}$, and additives like $\mathrm{NH}_{4} \mathrm{Cl}$ or $\mathrm{MgCl}_{2}$ were tested and high Pd leaching was obtained for long periods (30 - 60 mins) with low Al contamination.

Kasuya et al. [35] introduced a novel method for the recovery of the Pt, where the PGMs are dissolved in the $\mathrm{HCl}$ using complex oxides. Platinates were produced by calcining the mixture of $\mathrm{Pt} / \mathrm{Al}_{2} \mathrm{O}_{3}$ and alkali metal salts. The formation reaction of platinates includes $\mathrm{O}_{2}$ and $\mathrm{CO}_{2}$ (equation 11, where $\mathrm{M}=\mathrm{Li} \& \mathrm{Na}$ ). At $600{ }^{\circ} \mathrm{C}$, Pt is converted into $\mathrm{Li}_{2} \mathrm{PtO}_{3}$ when reacted with $\mathrm{Li}_{2} \mathrm{CO}_{3}$. This promotes the fact that alkali metal salts enhance the oxidation of Pt.

$$
\mathrm{Pt}+\mathrm{M}_{2} \mathrm{CO}_{3}+\mathrm{O}_{2} \rightarrow \mathrm{M}_{2} \mathrm{PtO}_{3}+\mathrm{CO}_{2}
$$

The platinates obtained are leached in $\mathrm{HCl}\left(12 \mathrm{~mol} . \mathrm{L}^{-1}\right)$ at $180{ }^{\circ} \mathrm{C}$ for $120 \mathrm{mins}$, the solubility of Pt was nearly $100 \%$ with proper dissolution conditions. The PGMs recovery through the leaching process from the spent catalyst is adopted widely due to its simple technique. The disadvantage with the process is the low recovery of PGMs, especially rhodium, also it is a difficult process to extract PGMs from low grade spent catalysts.

A microwave (MW) assisted PGMs extraction process was performed by Spooren and Atia [36]. The spent catalyst of about $1 \mathrm{~g}$ was initially milled and mixed with the sulfate salt (7.5 g NaHSO $4 . \mathrm{H}_{2} \mathrm{O}, 8.37 \mathrm{~g} \mathrm{KHSO}_{4}$ or $0.5 \mathrm{~g} \mathrm{H}_{2} \mathrm{SO}_{4}$ solution) and oxidation agent $\left(2.5 \mathrm{~g} \mathrm{NaClO}_{3}, 5\right.$ $\mathrm{ml} \mathrm{NaOCl}$ or $5 \mathrm{ml} \mathrm{H}_{2} \mathrm{O}_{2}$ ). They were well mixed by pestle and mortar, transferred to the ceramic crucible and MW roasted at $750 \mathrm{~W}$ for 30 mins. The roasted mixture was leached using $100 \mathrm{ml}$ of de-ionized water for 30 mins at $60{ }^{\circ} \mathrm{C}$. The slurry was cooled at room temperature and the solid residue was separated and dried at $105{ }^{\circ} \mathrm{C}$. The remaining leachate was analyzed to determine the presence of PGMs (see figure 4).

It was observed that the leachability rate of PGMs while using $1 \mathrm{M} \mathrm{HCl}$ instead of deionized significantly improved. The ideal parameters suggested for the recovery of the PGMs after the studies were as follows:

$\square$ the salt: spent catalyst ratio of 5

- $\mathrm{NaClO}_{3}: \mathrm{NaHSO}_{4} \cdot \mathrm{H}_{2} \mathrm{O}$ molar ratio of 0.05

$\square$ the liquid to a salt ratio of 10 and $\mathrm{HCl}=1 \mathrm{M}$,

At the above conditions the leachabilities for Pd, Pt, and Rh of $96 \pm 1 \%, 85 \pm 5 \%$, and $>96 \%$ were achieved respectively. The concentration of $\mathrm{Pd}, \mathrm{Pt}$, and $\mathrm{Rh}$ in the solid residue of $0.34 \mathrm{~g}$ were measured to be $97 \pm 18 \mathrm{mg} / \mathrm{kg}, 207 \pm 66 \mathrm{mg} / \mathrm{kg}$ and $<20 \mathrm{mg} / \mathrm{kg}$, respectively. It can be highlighted that when leaching the mixture without $\mathrm{NaClO}_{3}$, the leaching efficiency for $\mathrm{Pd}$ and $\mathrm{Rh}$ was low, and it was $0 \%$ for Pt. Although using $\mathrm{KHSO}_{4}$ salt resulted in a slightly higher leachability rate of $\mathrm{Pt}$, using $\mathrm{NaHSO}_{4}$ was considered economically friendly. 


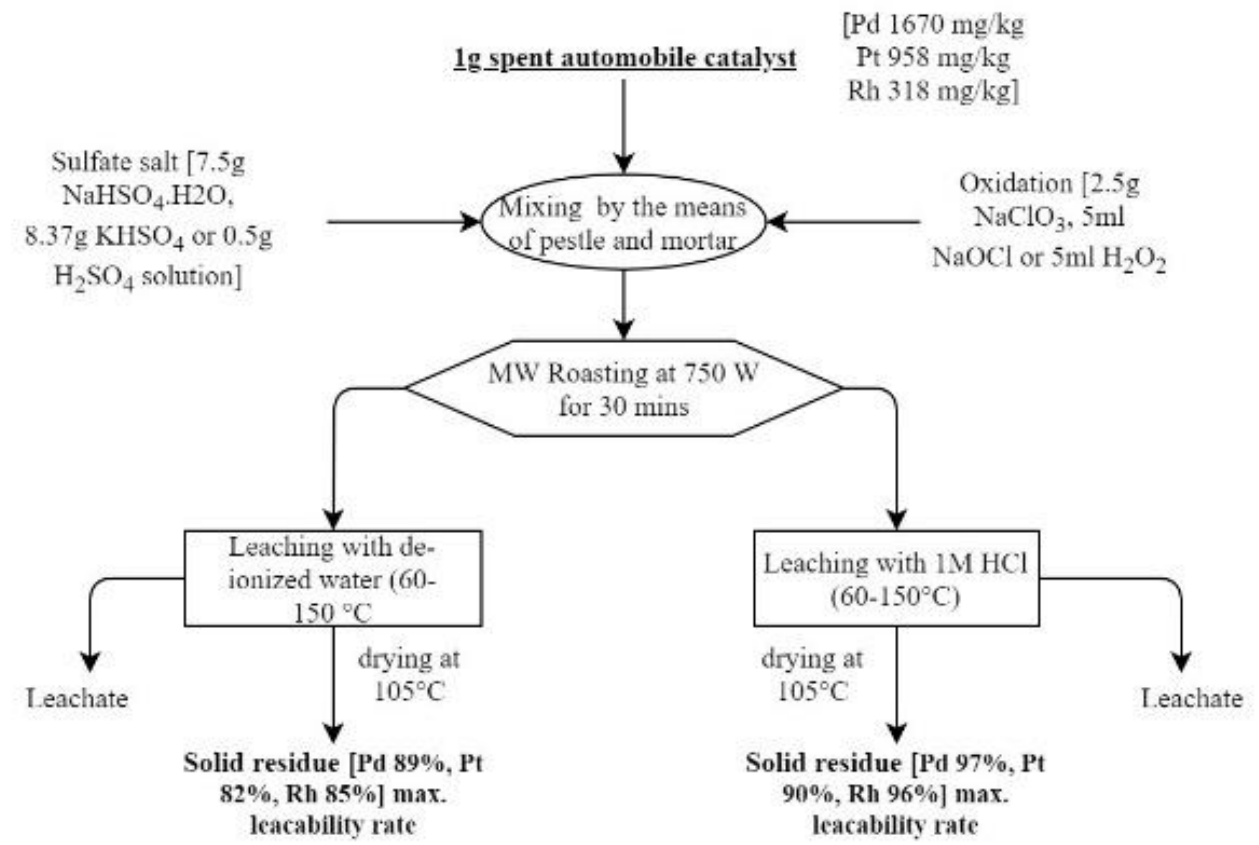

Figure 4. PFD of microwave-assisted extraction process [36]

In [37, 38], novel Phosphonium $\left(\mathrm{P}_{8,8,8,12} \mathrm{Cl}\right)$-based ionic liquid was used to separate the PGMs from the automobile leach liquor. Initially, $570 \mathrm{~g}$ of the spent catalyst was mechanically crushed followed by ball milling for 30 to 300 mins until the particle size of $75 \mu \mathrm{m}$ is attained. The leaching process was performed using $\mathrm{HCl}$ with 5 mol. $\mathrm{L}^{-1}$ concentration for 2 days at $70{ }^{\circ} \mathrm{C}$. The $\mathrm{P}_{8,8,8,12} \mathrm{Cl}$ was added to the leachate and centrifuged at $8000 \mathrm{rpm}$ for $5 \mathrm{~min}$. The $\mathrm{Pd}$ was extracted (reaction 12) within 5 mins while the extraction of $\mathrm{Rh}$ from the raffinate to $\mathrm{P}_{8,8,8,12} \mathrm{Cl}$ is performed after the removal of Pd and Pt. The process is highly efficient in the extraction of PGMs. Scrubbing of $\mathrm{Fe}$ is performed using $1.2 \mathrm{M} \mathrm{Na} \mathrm{SO}_{3}$ while the PGMs stripping (back extraction) from the complex ion is performed by the required solutions accordingly (see figure $5)$.

$$
\left[\mathrm{PdCl}_{4}\right]_{\mathrm{aq}}^{2-}+2 \mathrm{P}_{8,8,8,12} \mathrm{Cl} \rightarrow\left[\mathrm{P}_{8,8,8,12}\right]_{2} \mathrm{PdCl}_{4}+2 \mathrm{Cl}_{\mathrm{aq}}^{-}
$$

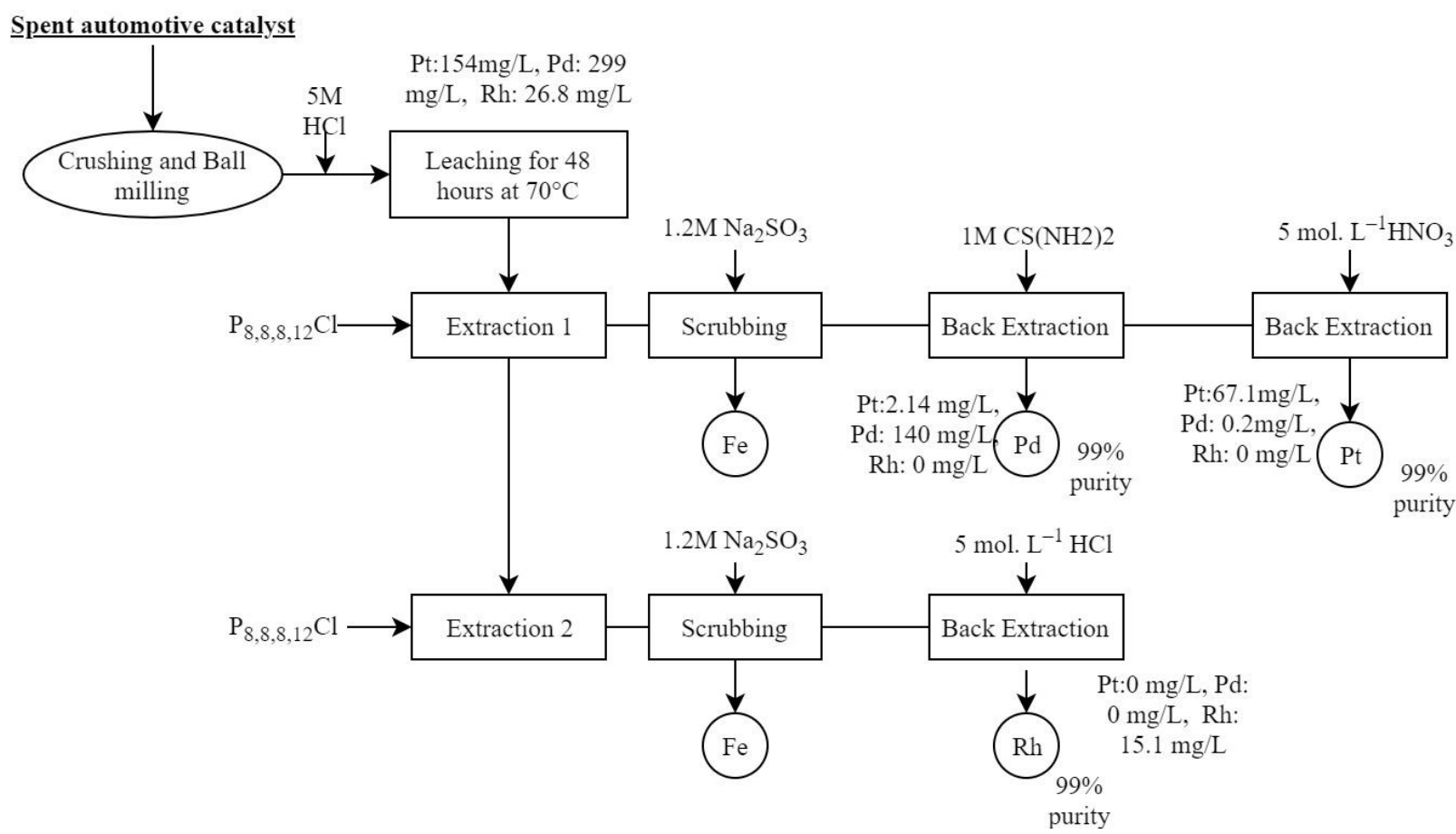

Figure 5. PFD of novel separation method $[37,38]$ 


\subsubsection{Cyanide solution leaching}

Industries have desired to recover PGMs by using cyanide-leaching technology for decades [39-41]. The following equations are the dissolution reactions occurring while using cyanide solution:

$$
\begin{gathered}
2 \mathrm{Pd}+8 \mathrm{NaCN}+\mathrm{O}_{2}+2 \mathrm{H}_{2} \mathrm{O} \rightarrow 2 \mathrm{Na}_{2}\left[\mathrm{Pd}(\mathrm{CN})_{4}\right]+4 \mathrm{NaOH} \\
2 \mathrm{Pt}+8 \mathrm{NaCN}+\mathrm{O}_{2}+2 \mathrm{H}_{2} \mathrm{O} \rightarrow 2 \mathrm{Na}_{2}\left[\mathrm{Pt}(\mathrm{CN})_{4}\right]+4 \mathrm{NaOH} \\
\mathrm{Rh}+24 \mathrm{NaCN}+3 \mathrm{O}_{2}+6 \mathrm{H}_{2} \mathrm{O} \rightarrow 4 \mathrm{Na}_{3}\left[\mathrm{Rh}(\mathrm{CN})_{6}\right]+12 \mathrm{NaOH}
\end{gathered}
$$

The decomposition of cyanide occurring while reacting with the oxidizing agent is as follows:

$$
\begin{gathered}
\mathrm{CN}^{-}+\mathrm{H}_{2} \mathrm{O} \rightarrow \mathrm{HCN}+\mathrm{OH}^{-} \\
2 \mathrm{HCN}+\mathrm{O}_{2}+2 \mathrm{H}_{2} \mathrm{O} \rightarrow 2 \mathrm{NH}_{3}+2 \mathrm{CO}_{2}
\end{gathered}
$$

Shams et al. [42] reported a process where the spent catalyst was first crushed into small particles while its size was determined by a mesh size sieved to find the dependency of the particle size with the recovery of PGMs. The spent catalysts are leached with $1 \mathrm{wt} . \%$ of $\mathrm{NaCN}$ at $160-180{ }^{\circ} \mathrm{C}$ at a pressure between 618 and $1002 \mathrm{kPa}$ for an hour. The weight ratio between the sodium cyanide solution and the spent catalyst is $2: 1$. To prevent sintering, the spent catalyst was decoked at a temperature range of $450-480{ }^{\circ} \mathrm{C}$. Pt in the form of anion $\mathrm{Pt}[\mathrm{CN}] 4^{2-}$ is replaced by anion $\mathrm{Cl}^{-}$in an ion exchange reaction with the resultant being $\left.\mathrm{N}^{+}\left(\mathrm{CH}_{3}\right)_{3}\right]_{2} \mathrm{Pt}[\mathrm{CN}]_{4}{ }^{2-}$ (Styrene divinylbenzene copolymer) formation. It was observed that the decoking of the coked catalyst is not required at high-temperature cyanide leaching. With the decrease in the particle size of the catalyst, the Pt recovery increases. At 2:1 weight ratio of $\mathrm{NaCN}$ and catalyst and temperature between 140 and $180^{\circ} \mathrm{C}$, optimum results were attained.

Chen et al. [41] investigated the recovery of PGMs from spent catalyst with $\mathrm{NaCN}$ leaching. The recovery of $\mathrm{Pt}$ is $96 \%, \mathrm{Pd}$ is $98 \%$ and $\mathrm{Rh}$ is $92 \%$ with an oxygen pressure of 1.5 $\mathrm{MPa}, \mathrm{NaCN} 0.1275 \mathrm{~mol}$. $\mathrm{L}^{-1}, \mathrm{NaCN}$ to catalyst ratio of $4: 1$ at around $160{ }^{\circ} \mathrm{C}$. The cyanide leaching order was $\mathrm{Pt}>\mathrm{Pd}>\mathrm{Rh}$, due to the complex ions metal bonding strength. The cyanide leaching process is highly toxic at high temperatures and still difficult to be implemented at the industrial level. The optimization of the method is still highly considered.

\subsubsection{Bioleaching}

In bioleaching, the microorganisms with their metabolites are used to extract metals from the spent catalyst. This process is eco-friendly and cost-efficient when compared to other leaching techniques [43]. The bioleaching method can be in two ways, direct (one or two-step process) or an indirect two-step process. In the one-step process (direct), fermentation and leaching take place at the same time, which means that the metal leaching and microorganism cultivation happen at the same time. In the two-step (direct) process, the cultivation takes place before the leaching even though both the processes takes place in the same container. In an indirect process, the leaching process takes place in the spent medium (microorganism free medium obtain through fermentation) $[44,45]$.

Malekian et al. [46] conducted an experiment for the Pt recovery through bioleaching, (Aspergillus niger produced oxalic acid solution) was investigated, where direct (one-step, twostep) and indirect (spent medium bioleaching with and without $\mathrm{pH}$ control) process were performed. It was observed that the production of oxalic acid and Pt recovery were higher with the $\mathrm{pH}$-controlled process. The optimal conditions were: $0.5 \mathrm{pH}, 1$ wt. \% of pulp and bioleaching 
temperature of $70{ }^{\circ} \mathrm{C}$, which resulted in $37 \%$ recovery of Pt. By replacing $\mathrm{HNO}_{3}$ with $\mathrm{HCl}$, the $\mathrm{pH}$ value was adjusted resulting in the increase of $\mathrm{Pt}$ recovery to $41 \%$. The bioleaching process is extensively used at industrial scale to recover metals like $\mathrm{Ni}, \mathrm{V}$, and Mo but is still under study for the PGMs recovery. The recovery of the PGMs by using bioleaching is low when compared with the conventional methods, but still the former is environmentally friendly, energy-efficient while the latter is hazardous, and energy-consuming process. Improvements can be made to increase the PGM recovery percentage by optimizing the process accordingly.

\subsubsection{Supercritical fluids oxidation}

The use of supercritical fluids (SF) is an alternative method of PGMs extraction, which is eco-friendly, low energy, easy recycling, good sensitivity and facile. SFs are used for different types of reactions as unique solvents [47]. It is known that creating an SF is simple: by moving the substance beyond its critical point (critical temperature, critical pressure) with increasing the temperature and pressure, supercritical fluids are obtained. Due to its relatively low critical temperature and pressure $\left(\mathrm{T}_{\mathrm{c}}=31.1^{\circ} \mathrm{C}, \mathrm{P}_{\mathrm{c}}=7.38 \mathrm{MPa}\right), \mathrm{CO}_{2}$ is considered as the best substance to make supercritical fluid. $\mathrm{CO}_{2}$ is low in cost, reactivity, and toxicity and also widely available. Supercritical $\mathrm{CO}_{2}$ can be used to extract nonpolar and slightly polar substances such as aldehydes, alkanes, terpenes, esters and alcohols [48].

By using the modifiers (polar: acetone, methanol \& nonpolar: propane, octane), the solubility of polar and nonpolar solids in $\mathrm{SF} \mathrm{CO}_{2}$ can be enhanced. In the SF solution, low concentrations (5 vol. \%) of modifiers are added. As $\mathrm{SF} \mathrm{CO}_{2}$ possesses low polarizability, the addition of modifiers improves this property and the same was stated in the papers $[49,50]$. Faisal et al. [51] conducted an experiment to determine the extraction of PGMs using the supercritical $\mathrm{CO}_{2}$ in combination with tributyl phosphate, no extraction of PGMs was observed. $\mathrm{HNO}_{3}$ ligand was introduced into the system and above $96 \%$ of Pd extraction was attained. It is also stated that the present process is not suitable for the recovery of $\mathrm{Pt}$ and $\mathrm{Rh}$ (as less than 3\% of these metals are recovered). The optimal conditions for the extraction process are when it is performed at $60{ }^{\circ} \mathrm{C}, 20 \mathrm{MPa}$ for $60 \mathrm{~min}$ of static extraction time. Supercritical water was used for the recovery of PGMs from the homogeneous precious metal catalysts by Collard et al. [52]. At 500 to $600{ }^{\circ} \mathrm{C}$ with $30 \mathrm{MPa}$ and oxygen injection (0-15\%), over 95\% of leaching rates for $\mathrm{Pt}, \mathrm{Pd}$ and $\mathrm{Rh}$ from organic catalyst was attained. The process has been effective but limited to only certain types of catalysts.

\subsubsection{Supported liquid membranes}

The possibility of utilizing thin layers of organic solutions (supported liquid membranes, SLM), immobilized on microporous inert supports interposed between two aqueous solutions (feed and strip), for removing selectively metal ions (A) from a mixture (AB+...) was first proposed more than 55 years ago [53]. The schematic representation of the process is shown in Figure 6. In some processes, the addition $(\boldsymbol{C})$ is added to the strip to form the insoluble compound $(\boldsymbol{A C})$.

The general problems of using this technique are connected with the membrane instability due to the pressure difference, the carrier and membrane dissolution, the presence of osmotic pressure, and other issues described in [54]. Since it was first proposed, supported liquid membrane technology has been used for the separation of a wide range of metals ions [55]. 


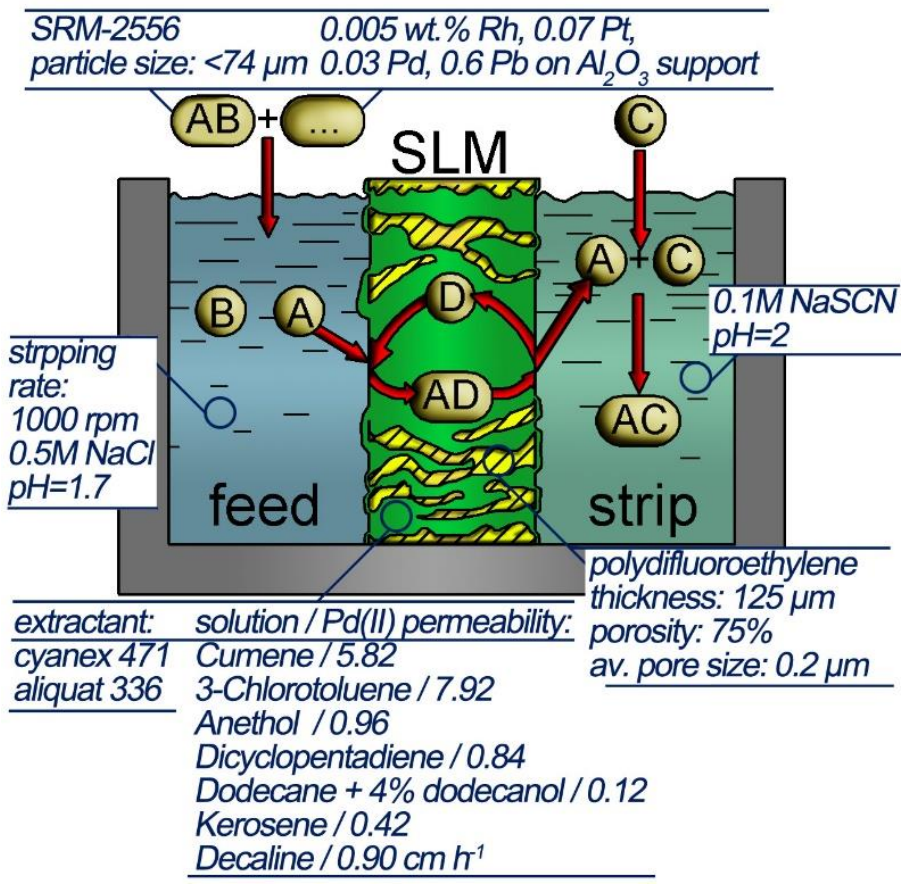

Figure 6. Schematic representation of supported liquid membrane [55, 56]

Fontas et al. [56, 57] described the new system combining two hollow-fiber-supported liquid membranes for the separation and concentration of platinum, palladium, and rhodium from spent automotive catalytic converters. Selective separation of these metals was achieved when the feed solution (to which a small amount of thiocyanate had been added) was first introduced into the HFLM system containing Cyanex 471 (triisobuthylphosphine sulfide) as the extractant and then passed through the second liquid membrane system consisting of Aliquat 336 (Tricaprylmethylammonium chloride) as the carrier. Only an insignificant amount of aluminum was co-transported. In the later work [57], palladium separation and concentration was achieved in a single step when using the liquid membrane system in hollow fiber geometry. Its efficiency has been demonstrated working with real solutions of PGMs obtained from the leaching of automotive catalysts, where palladium has efficiently been separated and concentrated, while no platinum extraction was observed. More developments of supported liquid membranes technique are described elsewhere [58].

\subsection{Pyrometallurgy}

In the pyrometallurgical process, the spent catalyst is transformed physically and chemically by performing a thermal treatment. Calcination, chlorination, and PGM smelting collection are considered as the three kinds of pyrometallurgical technologies [59, 60]. These technologies can be performed at a higher rate compared to the hydrometallurgical processes, as in the latter case there is no geometrical significance for the scrap materials used in the extraction of PGMs. In this process, a high amount of energy is consumed and leads to the emission of $\mathrm{SO}_{2}$, which is an environmental hazard [61].

\subsubsection{Sintering process}

The sintering process was performed by Bronshtein et al. [62] to extract the PGMs with high efficiency by mixing the spent catalyst with the metal chloride salts including (for $\mathrm{Pd}$ extraction)/ excluding (for Pt extraction) fumed silica powder. Two procedures were followed: in procedure \#1, $\mathrm{CaCl}_{2}$ was mixed with the crushed catalyst materials under dry conditions and in procedure \#2, the spent catalyst was immersed in the aqueous calcium chloride solution followed by drying. An optimal chloride salt to catalyst ratio was $6.7: 2.5$ for procedure \#2. During the 
experiment, continuous airflow was provided into the reactor. In procedure \#1, the sintering process was performed for 120 mins and Pt extraction efficiency did not exceed $63 \pm 3 \%$ for the temperatures between 500 to $1000{ }^{\circ} \mathrm{C}$. The calcium hypochlorite addition (20\% w.r.t. catalyst wt. $\%$ ) to the dry mixture improved the extraction efficiency to $74 \pm 4 \%$. In procedure \#2, the extraction efficiency of Pt was up to $80 \pm 4 \%$, the addition of ammonium chloride and sodium chloride salts as a supplement to the mixture to enhance the Pt extraction did not show any positive effect. At $1100{ }^{\circ} \mathrm{C}$, Pt was $100 \%$ extracted from the catalyst mixture using the procedure \#2.

The Pd extraction by using procedures \#1 and \#2 was poor $(<3 \%)$, fumed silica paste was used as an additive and a significant improvement in the extraction efficiency was observed $(76 \pm 4 \%)$ when sintered between 1000 to $1100{ }^{\circ} \mathrm{C}$. The addition of silica paste leads to a significant negative Gibbs energy for the reaction to form $\mathrm{CaSiO}_{3}$ from $\mathrm{CaO}$ and $\mathrm{SiO}_{2}$ (equation 18) $\left(\Delta \mathrm{G}^{0}=-220 \mathrm{KJ} / \mathrm{mol}\right.$ at $\left.\mathrm{T}=1100{ }^{\circ} \mathrm{C}\right)$ and without the silica paste addition, the $\Delta \mathrm{G}^{0}=-45$ $\mathrm{KJ} / \mathrm{mol}$.

$$
2 \mathrm{Pd}+2 \mathrm{CaCl}_{2}+2 \mathrm{SiO}_{2}+\mathrm{O}_{2}(\text { gas }) \rightarrow 2 \mathrm{PdCl}_{2}(\text { gas })+2 \mathrm{CaSiO}_{3}
$$

The primary advantage of the process is that it does not use strong acids or bases, no corrosive gases, and no hazardous chemicals. It produces nontoxic silicate waste as a by-product, which is minimal.

\subsubsection{Chlorination process}

In this process, the PGMs from the spent catalysts are transformed into their respective chlorides at high temperatures [63]. The PGMs are then separated based on the difference between the metal chlorides or by adsorption on an activated carbon bed or by repulp washing [40]. Murray et al. [64] in his patent mentioned that the PGMs in the spent catalyst are converted into chlorides in a chlorine gas/fluid field at 600 to $1200{ }^{\circ} \mathrm{C}$. The separation is then carried out by absorption of PGM chlorides by ammonium chloride liquor or water. The recovery of $\mathrm{Pd}, \mathrm{Pt}$, and Rh were up to 80-90\%, 80-90\%, and 85-90\% respectively.

Horike et al. [65] proposed a chlorination process for an efficient $\mathrm{Pt}$ recovery. $\mathrm{CuCl}_{2}$ was used as a chlorine solution for the chlorination of $\mathrm{Pt}$ at 400 to $600{ }^{\circ} \mathrm{C}$. Due to high chemical stability, pure $\mathrm{Pt}$ was insoluble in $\mathrm{HCl}$ (aq), scrap containing $\mathrm{Pt}$ was then alloyed with $\mathrm{Mg}$ and physically mixed with $\mathrm{CuCl}_{2}$ at $500{ }^{\circ} \mathrm{C}$ and then dissolved in $\mathrm{HCl}$ (aq). The solubility of $\mathrm{Pt}$ in the $\mathrm{HCl}(\mathrm{aq})$ improved after the chlorination process. The recovery of $\mathrm{Pt}$ through this process can be environmentally friendly.

$\mathrm{Xu}$ et al. [66] proposed a method where the spent catalyst was pre-treated by crushing, roasting, and reducing. Then $\mathrm{NaCl}$ was added to it to perform chlorination at $600-700{ }^{\circ} \mathrm{C}$. The mixture was then dealt with by the hot water and steam, resulting in PGM chloride salt solution. The recovery of $\mathrm{Pd}, \mathrm{Pt}$, and $\mathrm{Rh}$ was up to $90 \%$. This process is not adaptable to the industrial scale as it results in the emission of toxic gases, high equipment requirement, and is performed at high temperatures.

\subsubsection{Metal smelting collection}

In this process, the spent catalysts are mixed with flux, collector and reducing agent and then smelted in a high-temperature electric arc or plasma furnace or induction furnaces at around $1000{ }^{\circ} \mathrm{C}$ (Figure 7). PGMs are converted into easily treatable complex ions and later refined to recover the PGMs. The pre-treatment processes such as the dismantling of non-metallic components, calcination or reduction are performed before the smelting, which is done at high temperatures with the addition of collectors (with high specific gravity) such as lead, iron, copper. The PGMs form an alloy with the collectors; at the same time catalysts, carriers are 
melted in the presence of flux to form a slug with the low viscosity. Then the separation procedure is performed were the PGM enriched alloy is separated from the slag and the purification process is done. High recovery rates of PGM are expected from this process [67].

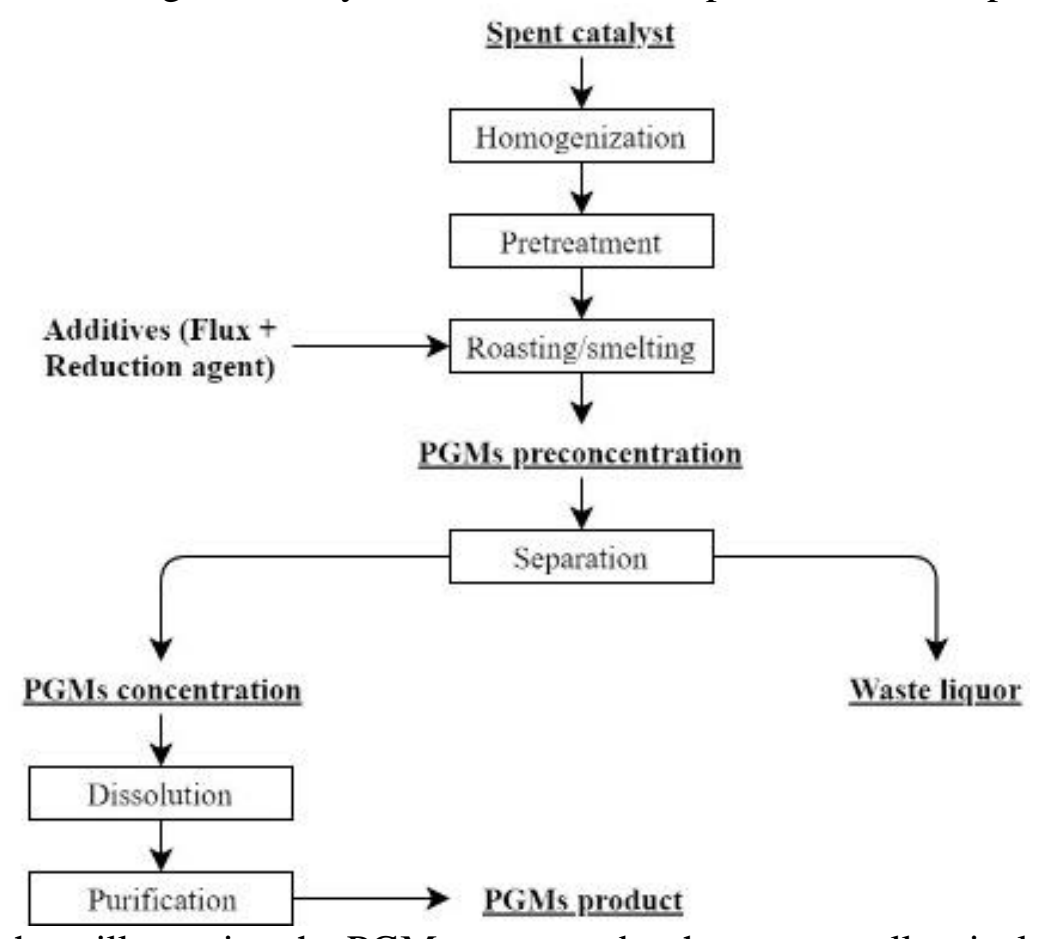

Figure 7. Flowsheet illustrating the PGMs recovery by the pyrometallurgical process

The lead collection is the oldest method used to recover PGMs from the spent catalyst [68]. In this process, the spent catalyst is crushed and then added to a mixture containing $\mathrm{PbO}$, anhydrous borax, sodium carbonate, and potassium bitartrate, which is then smelted for $2 \mathrm{~h}$ at $1100{ }^{\circ} \mathrm{C}$. The $\mathrm{PbO}$ is reduced to $\mathrm{Pb}$, forming an alloy with the $\mathrm{PGMs}$ while $\mathrm{SO}_{2}$ from the catalyst is oxidized to form a slag namely borosilicate, which floats on top of the molten lead layer. The borosilicate slag is removed and molten $\mathrm{Pb}$ containing PGMs is left for purification. This process is easy to operate and $\mathrm{Pt}$ recovery is highly efficient but also has disadvantages: the $\mathrm{Rh}$ recovery being less than $80 \%$ and the emission of toxic $\mathrm{PbO}$ gas.

The copper collection process is recommended for the spent catalyst containing cordierite carriers [69-71]. The copper collectors are $\mathrm{CuCO}_{3}, \mathrm{CuO}$, or $\mathrm{Cu}$ with the flux being $\mathrm{SiO}_{2}, \mathrm{CaO}$, and the reducing agent is usually powder coke. The collector, the flux, the reducing agent and the spent catalyst mixture is placed in an induction furnace and smelted at $1400{ }^{\circ} \mathrm{C}$. PGMs are collected at low temperature under ambient atmosphere. The ceramic carriers of the PGMs form a slag on the top of the molten copper, which can be poured out easily. The PGM contained copper is cast into anodes and electrolysis is performed. A slime containing 25\% of PGMs is obtained after the electrolysis, $99 \%$ of PGMs can be recovered overall through this process.

Using iron as a collector is economically beneficial. Fe shows a strong chemical affinity towards the PGMs [72]. The crushed spent catalyst mixed with the flux $(\mathrm{CaO}), \mathrm{Fe}$ powder, and reducing agent (powder coke) is smelted in a plasma arc furnace at $1500-2000{ }^{\circ} \mathrm{C}$. The PGM enriched $\mathrm{Fe}$ alloy and the carrier slag can be easily separated because of their large densities differences (density ratio $=2: 1$ ). The recovery rates of $\mathrm{Pd}, \mathrm{Pt}$, and $\mathrm{Rh}$ were over $98 \%, 98 \%$, and $97 \%$, respectively [73].

The matte collection is a relatively new method used for the recovery of PGM from spent catalyst $[74,75]$. When the spent catalyst is smelted, a matte type substance is formed, which acts as a collector of PGMs. PGMs enriched matte is obtained at 1000 to $1450{ }^{\circ} \mathrm{C}$ by adding Ni or NiS and the flux $\left(\mathrm{Na}_{2} \mathrm{~B}_{4} \mathrm{O}_{7}, \mathrm{Na}_{2} \mathrm{CO}_{3}, \mathrm{CaO}\right)$. You et al. [76] reported that nickel and sulfur can be used as collectors in the smelting of spent catalyst in the presence of borax and sodium 
carbonate for $30 \mathrm{~min}$ at $1050{ }^{\circ} \mathrm{C}$. The recoveries of $\mathrm{Pd}, \mathrm{Pt}$, and $\mathrm{Rh}$ were $93 \%, 90 \%$, and $88 \%$ respectively for this process.

A novel Pd recovery method was proposed by Zhang et al. [77] where the eutectic copper is used to capture Pd from the spent automobile catalyst. The recovery of Pd is difficult compared to the rest of the PGMs, as the element possesses inert behavior [78]. $\mathrm{Cu}$ is used as a capture agent, where Pd forms an alloy with $\mathrm{Cu}$ at a temperature above $1250{ }^{\circ} \mathrm{C}$. The studies were conducted at temperatures between 1200 and $1400^{\circ} \mathrm{C}$. The spent catalyst mainly comprised of cordierite ( $\left.2 \mathrm{MgO}: 2 \mathrm{Al}_{2} \mathrm{O}_{3}: 5 \mathrm{SiO}_{2}\right)$, aluminum oxide, and $1650 \mathrm{mg} / \mathrm{kg}$ of Pd. The spent catalyst sample was transferred to a crucible along with $\mathrm{CuO}, 5 \mathrm{wt} \% \mathrm{C}, 30$ wt.\% $\mathrm{CaO}, 20$ wt \% $\mathrm{SiO}_{2}, 10$ wt. \% borax, and $8 \mathrm{wt} . \% \mathrm{Na}_{2} \mathrm{CO}_{3}$, where borax and $\mathrm{Na}_{2} \mathrm{CO}_{3}$ enhances the melting of the slag. The $\mathrm{CaO}-\mathrm{SiO}_{2}-\mathrm{Al}_{2} \mathrm{O}_{3}$ glass phase, which plays a key role in the formation of $\mathrm{Cu}-\mathrm{Pd}$ alloy, is expected to formed. At $1200{ }^{\circ} \mathrm{C}$, the recovery of Pd was $0 \%$ as the spent catalyst was not in the molten form. At $1250{ }^{\circ} \mathrm{C}$, the Pd recovery reached $90 \%$ and was up to $100 \%$ when the operating temperature reached $1400{ }^{\circ} \mathrm{C}$. The authors suggested the optimal temperature to be $1350{ }^{\circ} \mathrm{C}$ where the Pd recovery rate was $97 \%$.

The metal smelting collection process can be implemented on a wide range of secondary materials, especially low grade, and refractory spent catalysts. Factors like collector materials, flux, reducing agents, operational conductions affect the efficiency of the process. Copper collection technology has relatively low cost, high efficiency, and low smelting temperature. The collector material can be re-used. Therefore, this method can be easily adapted to an industrial scale. It is also worth mentioning that adding metal collectors to the briquettes increases the PGM yielding and significantly decrease the dust-gas emission [79].

\subsection{Physical separation}

In the spent catalyst, the catalyst carriers are honeycomb-structured items with the porous catalyst layers on its surface. The PGMs are only present on these porous layers where a simple low-energy-consuming and low-cost process like physical separation can be implemented to separate the PGMs or PGM containing layer from the carrier would be significant to eliminate the toxic gases usually released from the regular recycling process. By pulverizing the spent catalyst, a magnetic separation technique can be employed to physically separate the PGMs from the catalyst carriers. The magnetic separation can be performed only on old catalysts with nickel content. Techniques like selective grinding followed by size separation $[80,81]$ and selective grinding followed by quenching/heat treatment [82] can enhance the PGM-containing catalyst layer concentration.

Taninouchi et al. [83] came up with a new process (Figure 8), where a magnetic separation technique is used to recover the PGMs from spent catalysts. 


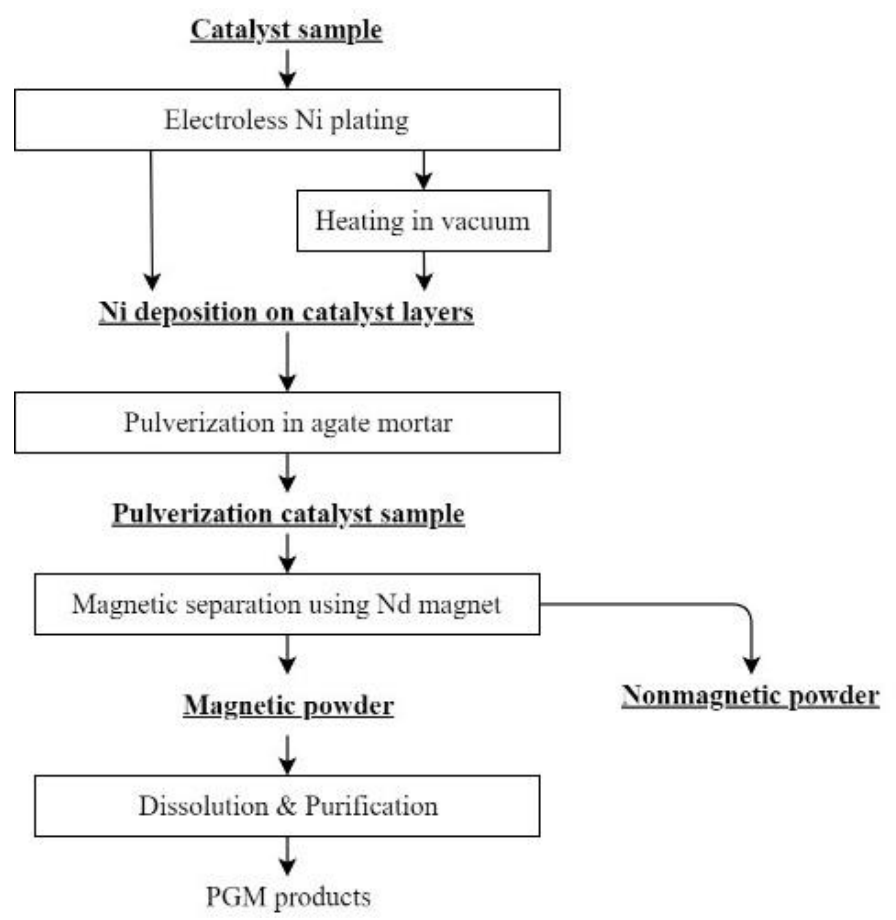

Figure 8. Flowchart illustrating physical concentration technique [83]

In this process, the Ni deposition on the PGMs is done by using an electroless-plating bath along with a complexing agent and reduction agent, which are glycine and sodium hypophosphite respectively. The composition of electroless plating bath $\left(\mathrm{NiSO}_{4} \cdot 6 \mathrm{H}_{2} \mathrm{O}=35.6\right.$ $\mathrm{c}^{\mathrm{i} / g} \cdot \mathrm{L}^{-1}$, glycine $=22.0 \mathrm{c} / \mathrm{g} \cdot \mathrm{L}^{-1}, \mathrm{NaHPO}_{2} . \mathrm{H}_{2} \mathrm{O}=24.1 \mathrm{c} / \mathrm{g} . \mathrm{L}^{-1}$ and $\mathrm{PbCl}_{2}=0.004 \mathrm{c}$ i $\left./ \mathrm{g} . \mathrm{L}^{-1}\right)$. The $\mathrm{pH}$ value was adjusted to $7.7 \pm 0.4$ at room temperature $\left(25^{\circ} \mathrm{C}\right)$ by using $\mathrm{NaOH}(\mathrm{aq}$.$) . The$ catalyst sample is immersed in the plating solution $(40 \mathrm{ml})$ at room temperature. The container with the catalyst sample and plating solution is then heated to $70{ }^{\circ} \mathrm{C}$ for $15 \mathrm{mins}$. The ferromagnetic nickel was plated on the surface of the porous catalyst layer successfully without additional steps like sensitization or activation. Crushing and pulverization were performed on catalyst samples. Neodymium magnet ( $\mathrm{Nd}-\mathrm{Fe}-\mathrm{B}$ alloy) was used for the magnetic separation process under dry conditions. Results from the separation process showed that this process can be further developed and can be adapted to the industrial scale.

The recovery of PGM by treating the spent catalyst with $\mathrm{FeCl}_{\mathrm{x}}(\mathrm{x}=2,3)$ was tested by Taninouchi et al $[84,85]$. The idea was to convert Pt into the Pt-Fe alloy, which exhibits ferromagnetic behavior. The $\mathrm{FeCl}_{2}$ vapor reacted with $\mathrm{Pt}$ samples under the coexistence of $\mathrm{Fe}$ metal at $927{ }^{\circ} \mathrm{C}$ for 60 mins, resulted in the formation of the $\gamma_{2}-\mathrm{FePt}$ ferromagnetic phase. Fe was transported from metallic $\mathrm{Fe}$ to $\mathrm{Pt}$ sample due to the disproportionation of $\mathrm{FeCl}_{2}$ vapor and the gaseous phase $\mathrm{FeCl}_{\mathrm{x}}$ acted as a mediator between the metals. When the $\gamma_{2}-\mathrm{FePt}$ alloy was exposed to $\mathrm{FeCl}_{3}$, Fe was removed from the alloy resulting in the loss of the magnetic property. It can be stated that $\mathrm{Pt}$ can be only treated with $\mathrm{FeCl}_{2}$ but not with $\mathrm{FeCl}_{3}$. Further tests were conducted on the rest of the PGMs and the result was the same. Pd and Rh formed alloys with Fe showing strong ferromagnetic character. The carriers like $\mathrm{Al}_{2} \mathrm{O}_{3}$ did not react with the $\mathrm{FeCl}_{2}$ but $\mathrm{La}_{2} \mathrm{O}_{3}$ and $\mathrm{CeO}_{2}$ were converted into their respective oxychlorides. Magnetic separation was effective on the PGMs after the $\mathrm{FeCl}_{2}$ vapor treatment. These processes showed promising results and have the potential to be used at a higher level. The process can be performed at a low cost with a quick pace and is environmentally friendly.

\subsection{Electrochemical techniques}

High-temperature electrochemical treatment can be applied to extract precious metals from spent catalysts. In general, the electrochemical methods are easy to arrange, can be 
performed with low waste emission and with low energy and reactant consumption. The major disadvantage is that these methods are not universal. They can be applied for the treatment of catalyst based on $\gamma-\mathrm{Al}_{2} \mathrm{O}_{3}$ carrier with a minor content of other oxides $\left(\mathrm{SiO}_{2}, \mathrm{Fe}_{2} \mathrm{O}_{3}, \mathrm{MgO}, \mathrm{TiO}_{2}\right.$, $\mathrm{CeO}_{2}$, etc.), however automotive exhaust gas convertors, which are catalysts with the highest annual amount can barely be successfully treated by electrochemical process due to their complexity. They generally have cordierite $\left(2 \mathrm{MgO} \cdot 2 \mathrm{Al}_{2} \mathrm{O}_{3} \cdot 5 \mathrm{SiO}_{2}\right)$ as a substrate coated with $\gamma$ $\mathrm{Al}_{2} \mathrm{O}_{3}$ wash-coat where precious metals (basically $\mathrm{Pt}, \mathrm{Pd}, \mathrm{Rh}$ ) are placed. Each of the oxide components requires separate treatment and adjustment of the technology.

\subsubsection{Two-step method}

Belov et al. [86, 87, 88] proposed an electrochemical method for the extraction of Pd from spent $\mathrm{Al}_{2} \mathrm{O}_{3}$-based catalysts, which was carried out in several stages, based on the HallHeroult process for the primary aluminum production and the three-layer refining process for the high-purity aluminum production (shown in Figure 9). These stages are:

1. Calcination of the catalysts at $800{ }^{\circ} \mathrm{C}$ under air (or oxygen) atmosphere to remove organic impurities and partially transform PGMs into oxides;

2. Dissolution of the catalysts in the molten fluoride system $\left(\mathrm{Na}_{3} \mathrm{AlF}_{6}-\mathrm{AlF}_{3}-\mathrm{CaF}_{2}\right)$, electrodeposition of aluminum and PGM on the cathode alloy with the simultaneous evolution of carbon dioxide on the carbon anode according to the reaction:

$$
\mathrm{Al}_{2} \mathrm{O}_{3} \text { (dis) }+1.5 \mathrm{C}(\mathrm{s}) \Rightarrow 2 \mathrm{Al}(\mathrm{l})+1.5 \mathrm{CO}_{2}(\mathrm{~g})
$$

3. Electrolytic refining of the $\mathrm{Al}-\mathrm{Cu}-\mathrm{PGM}$ alloy $(\mathrm{Cu}$ is added to heighten density) with electrodeposition of high-purity aluminum at the cathode and concentration of PGMs in the anode alloy.

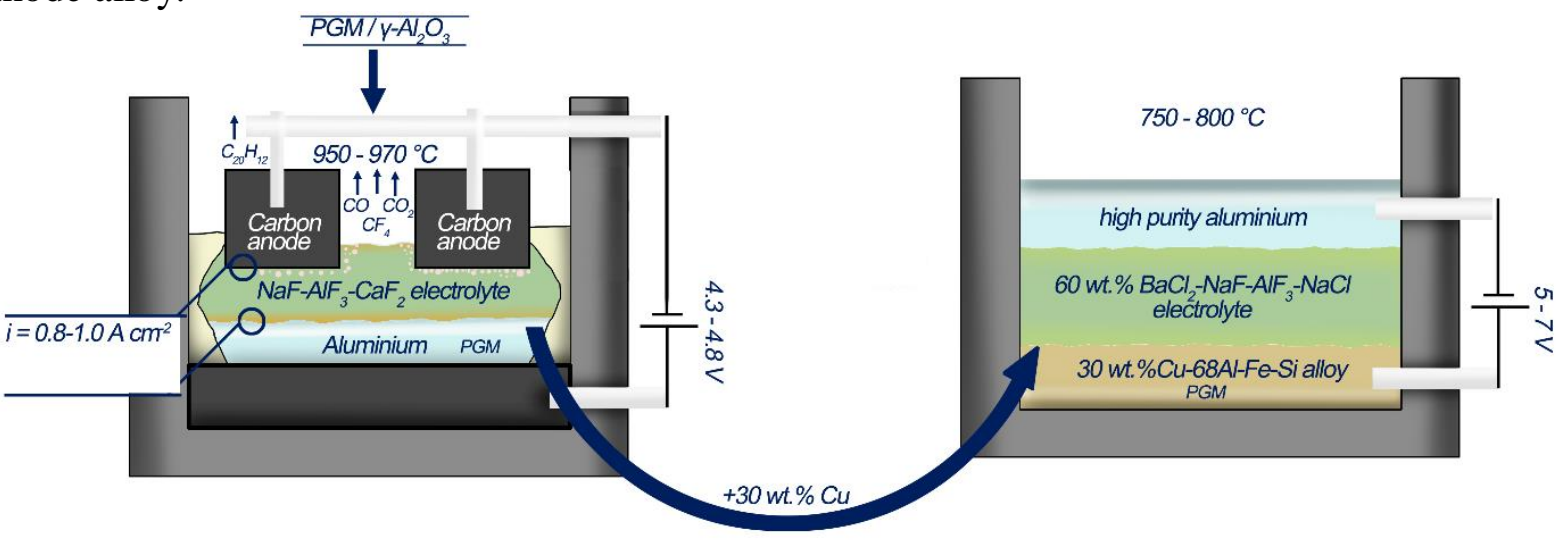

Figure 9. Schematic representation of the commercial Hall-Heroult Cell and the aluminum refinery cell [89]

This process requires high $\left(950-970{ }^{\circ} \mathrm{C}\right)$ temperature and should be operated within a narrow window of catalysts concentration to prevent the sludge formation and the emission of perfluorocarbons during low- or high-voltage anode effect that in case of slow dissolution can be a difficult problem to overcome.

Despite the mentioned considerations, several experimental facts confirm the perspectivity of the electrochemical extraction method [86-88]:

$\square \quad$ with the introduction of palladium oxide into molten cryolite, palladium is sufficiently fully reduced and dissolved in aluminum, while the addition of finely dispersed palladium to the melt leads to its appreciable distribution between aluminum and cryolite (in the latter, palladium forms suspension);

$\square$ palladium from the catalysts is dissolved and almost completely concentrated in primary aluminum (98-99\%); 
$\square$ replacing smelter grade alumina with the catalyst in the Hall-Heroult process has virtually no effect on the performance of the aluminum production;

$\square$ the presence of palladium in the anode alloy in the three-layer refining process has almost no effect on the current efficiency of the aluminum refining;

$\square$ high palladium extraction degree $(>98 \%)$ and the simultaneous production of high-purity aluminum (A97, A99) were achieved.

\subsubsection{One-step method}

The cost of noble metals extraction from spent catalysts can be significantly reduced by using a one-step electrochemical method. Moreover, the temperature of the process can be lowered to $700-850{ }^{\circ} \mathrm{C}$ by replacing sodium cryolite with low-temperature fluoride or chloride melts with considerable solubility of $\mathrm{Al}_{2} \mathrm{O}_{3}$. The promising option, the molten $1.3 \mathrm{KF}-\mathrm{AlF}_{3}$ system has been studied elsewhere [89-91]. Dividing the cell into two parts (half-cells) by supported vertical or unsupported horizontal liquid Al membrane (bipolar electrode) can be a beneficial solution for one-step extraction. The first half-cell acts as the aluminum reduction cell, the second one plays the role of the aluminum refinery cell. The schematic representation of the cell is shown in Figure 10.

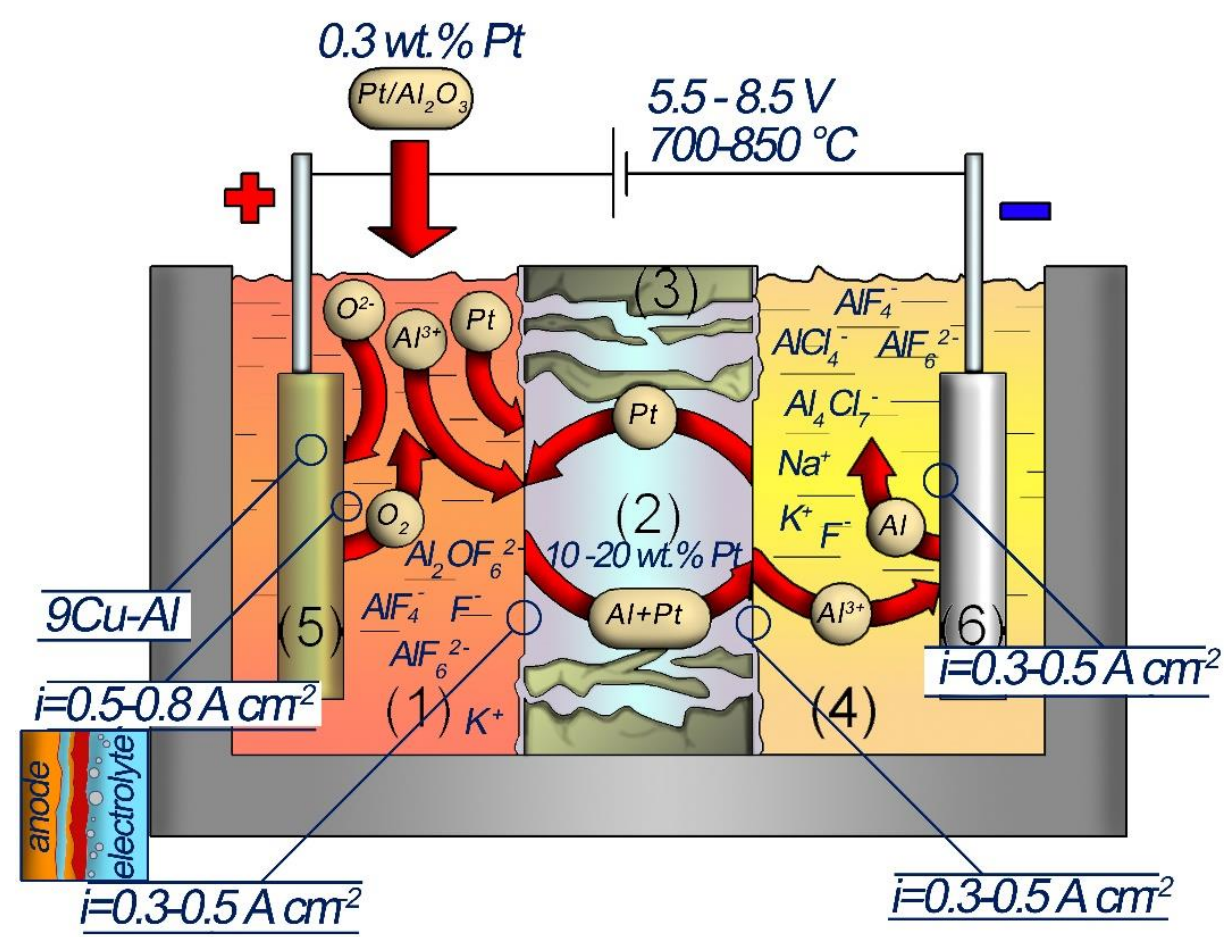

Figure 10. Concept of one-step electrometallurgical process, (1) $\mathrm{KF}-\mathrm{AlF}_{3}$ electrolyte for catalyst decomposition, (2) Al-based bipolar electrode, (3) wettable substrate $\mathrm{TiB}_{2}$ or $\mathrm{W}$ - optional, (4) $\mathrm{NaCl}-$ $\mathrm{KCl}-\mathrm{AlF}_{3}$ (+optional $\mathrm{BaCl}_{2}$ ) electrolyte for removing $\mathrm{Al}$ from the bipolar electrode, (5) oxygen-evolving anode, (6) cathode for high-purity aluminum evolution

This process is patented [92] and now is under the laboratory scale studies [93] with the spent $\mathrm{Pt}(+\mathrm{Re}) / \gamma \mathrm{Al}_{2} \mathrm{O}_{3}$ catalysts from the petrochemical industry with $0.35 \mathrm{wt} . \% \mathrm{Pt}$ and $0.2 \mathrm{wt} . \%$ $\operatorname{Re}$ (optional). The catalysts were calcined under air atmosphere in the electrical furnace at 800 ${ }^{\circ} \mathrm{C}$ for 30 mins with the manual stirring, ground and treated with mechanical activation for $10 \mathrm{~s}$ for better performance in terms of dissolution rate. The 24-hours experiment showed that Pt extraction reaches $99 \%$. This value obtained by comparing the Pt concentration in the bipolar electrode and high-purity aluminum. The detailed description of these results is a subject of 
640

641

642

643

644

645

646

647

648

649

650

651

652

653

654

655

656

657

658

659

660

661

662


Figure 11. Spent catalyst $\mathrm{Pt} / \mathrm{Al}_{2} \mathrm{O}_{3}$ : a) before sintering, b) after 10 minutes of calcining at $800{ }^{\circ} \mathrm{C}, \mathrm{c}$ ) after 30 minutes of calcining at $800{ }^{\circ} \mathrm{C}$ with manual stirring

While Pt is successfully concentrated in the alloy, Re requires additional effort to be extracted as it is oxidized in a wide range of temperatures. The boiling temperatures of rhenium oxides are lower than $620{ }^{\circ} \mathrm{C}$ that makes it difficult to extract it to the alloy. This is another drawback of this process when the catalyst contains Re.

The catalysts based on the cordierite can also be dissolved in molten cryolite. In that case, silicon (and iron) will be collected in the alloy along with precious metals. Magnesium will be collected in the refinery electrolyte in the form of $\mathrm{MgCl}_{2}$ due to the significant differences between the electrode potentials of $\mathrm{Al}$ and $\mathrm{Mg}$. The same is true for cerium, which will also be collected in the electrolyte in an oxidized form.

The complexity of cordierite (and another mineral supports as zeolites) makes the possibility of using the electrochemical technology for the treatment of spent catalysts other than $\mathrm{Al}_{2} \mathrm{O}_{3}$-based questionable. Major changes should be made to adjust this technology for different types of catalysts.

\subsection{Comparative analysis of the technologies}

The comparison between different approaches for the extraction of metals from spent catalysts is presented in table 2 .

Table 2. The comparison of different technologies for catalysts processing

\begin{tabular}{|c|c|c|c|c|c|c|c|c|}
\hline $\begin{array}{c}\text { Generic } \\
\text { composition } \\
(\text { wt.\%) }\end{array}$ & $\begin{array}{l}\text { Recycling } \\
\text { technology }\end{array}$ & $\begin{array}{l}\text { Operating } \\
\text { condition }\end{array}$ & $\begin{array}{c}\text { Recovery } \\
\text { effect }\end{array}$ & $\begin{array}{l}\text { Advantages and } \\
\text { disadvantages of } \\
\text { the recycling } \\
\text { process }\end{array}$ & $\begin{array}{c}\text { Impact on } \\
\text { environment and } \\
\text { pollutants } \\
\text { released }\end{array}$ & $\begin{array}{c}\text { Extractio } \\
\text { n\% }\end{array}$ & $\begin{array}{l}\text { Application } \\
\text { scale }\end{array}$ & Ref. \\
\hline $\begin{array}{l}\mathrm{Pt} / \mathrm{Al}_{2} \mathrm{O}_{3} \\
\mathrm{Pt}-0.35, \mathrm{Al}- \\
52.80, \mathrm{Fe}-0.02 \text {, } \\
\mathrm{C}-0.35\end{array}$ & $\begin{array}{l}\mathrm{HCl}+ \\
\mathrm{Cl}_{2} / \mathrm{NaClO} / \mathrm{Na} \\
\mathrm{ClO}_{3} \text { leaching }\end{array}$ & $\begin{array}{l}\text { Low operating } \\
\text { temperature }(60- \\
\left.150{ }^{\circ} \mathrm{C}\right) \text {, } \\
\mathrm{Emission} \\
\mathrm{SO}_{2}, \mathrm{Cl}_{2}\end{array}$ & $\begin{array}{l}\text { High } \mathrm{Pt}, \mathrm{Pd} \\
\text { and } \mathrm{Rh} \\
\text { recovery rate }\end{array}$ & $\begin{array}{l}\text { +High recovery } \\
\text { efficiency, +mature } \\
\text { technology, } \\
\text { +low toxicity, } \\
\text { +low investment and } \\
\text { cost }\end{array}$ & $\begin{array}{l}\text { Wastewater } \\
\text { pollution (heavy } \\
\text { metal ions); } \mathrm{Cl}_{2} \\
\text { emission }\end{array}$ & $\begin{array}{l}\text { Pd: } 99 \%, \\
\text { Pt: } 94 \% \\
\text { Rh: } 89 \%\end{array}$ & $\begin{array}{l}\text { Commercial } \\
\text { level }\end{array}$ & $23-31$ \\
\hline $\begin{array}{l}\mathrm{Pd} / \mathrm{Al}_{2} \mathrm{O}_{3} \\
\mathrm{PdO}_{2}-0.03 \% \\
\mathrm{CrO}_{3}-0.03 \% \\
\mathrm{Al}_{2} \mathrm{O}_{3} \text { matrix - } \\
99.94 \%\end{array}$ & $\begin{array}{l}\mathrm{HCl}+\mathrm{H}_{2} \mathrm{O}_{2} \\
\text { leaching }\end{array}$ & $\begin{array}{l}\text { Low operating } \\
\text { temperature }(60- \\
\left.150{ }^{\circ} \mathrm{C}\right) \text {, Low } \\
\text { emission of } \mathrm{Cl}_{2}\end{array}$ & $\begin{array}{l}\text { High } \mathrm{Pt}, \mathrm{Pd} \\
\text { and } \mathrm{Rh} \\
\text { recovery rate }\end{array}$ & $\begin{array}{l}\text { +High recovery } \\
\text { efficiency, } \\
\text { + mature } \\
\text { technology, } \\
\text { +negligible toxicity, } \\
\text { +low investment and } \\
\text { cost, short process }\end{array}$ & $\begin{array}{l}\text { Low } \\
\text { environmental } \\
\text { pollution due to } \\
\text { the low emission } \\
\text { of } \mathrm{Cl}_{2}\end{array}$ & $\begin{array}{l}\text { Pd: } 97 \%, \\
\text { Pt: } 90 \% \\
\text { Rh: }>97 \%\end{array}$ & $\begin{array}{l}\text { Commercial } \\
\text { level }\end{array}$ & $32-36$ \\
\hline $\begin{array}{l}\mathrm{Pt} / \mathrm{Al}_{2} \mathrm{O}_{3} \\
\mathrm{PtO}_{2}-0.56 \% \\
\mathrm{CdO}-0.44 \% \\
\mathrm{SiO}_{2}-0.17 \%\end{array}$ & $\begin{array}{l}\text { Cyanide } \\
\text { leaching }\end{array}$ & $\begin{array}{l}\text { Low operating } \\
\text { temperature }(60- \\
\left.150{ }^{\circ} \mathrm{C}\right) \text {, } \\
\text { Hazardous gases }\end{array}$ & $\begin{array}{l}\text { High } \mathrm{Pt}, \mathrm{Pd} \\
\text { and } \mathrm{Rh} \\
\text { recovery rate }\end{array}$ & $\begin{array}{l}\text { +Low recovery } \\
\text { efficiency, } \\
\text { +low investment and } \\
\text { cost }\end{array}$ & $\begin{array}{l}\text { Wastewater } \\
\text { pollution }\left(\mathrm{CN}^{-}\right) \text {; } \\
\text { HCN emission }\end{array}$ & $\begin{array}{l}\text { Pd: } 98 \% \text {, } \\
\text { Pt: } 96 \% \\
\text { Rh:92\% }\end{array}$ & $\begin{array}{l}\text { Laboratory } \\
\text { level }\end{array}$ & $39-41$ \\
\hline
\end{tabular}




\begin{tabular}{|c|c|c|c|c|c|c|c|c|}
\hline $\begin{array}{l}\mathrm{Al}_{2} \mathrm{O}_{3}-96.09 \% \\
\text { rest of the matrix } \\
<1 \%\end{array}$ & & emission & & $\begin{array}{l}\text {-immature } \\
\text { technology, } \\
\text {-high toxicity, }\end{array}$ & & & & \\
\hline $\begin{array}{l}\mathrm{Pt} / \mathrm{Al}_{2} \mathrm{O}_{3} \\
\mathrm{Pt}-0.307 \% \\
\mathrm{Cl}-1.43 \% \\
\mathrm{Fe}_{2} \mathrm{O}_{3}-0.343 \% \\
\mathrm{Al}_{2} \mathrm{O}_{3}-92.15 \% \\
\mathrm{Loss} \text { of } \\
\text { ignistion- } 4.95 \%\end{array}$ & Bioleaching & $\begin{array}{l}\text { Low operating } \\
\text { temperature, No } \\
\text { harmful gases } \\
\text { emitted }\end{array}$ & $\begin{array}{l}\text { moderate } \mathrm{Pt}, \\
\mathrm{Pd} \text { and } \mathrm{Rh} \\
\text { recovery rate }\end{array}$ & $\begin{array}{l}\text { +moderate recovery } \\
\text { efficiency (relatively } \\
\text { new process for the } \\
\text { recovery of PGMs), } \\
\text { +non-toxicity, +low } \\
\text { investment and cost, } \\
\text { +low energy } \\
\text { consumption, - } \\
\text { immature } \\
\text { technology -low } \\
\text { extraction rate }\end{array}$ & $\begin{array}{l}\text { Environmentally } \\
\text { friendly, no } \\
\text { chemical emission }\end{array}$ & Pt: $41 \%$ & $\begin{array}{l}\text { Laboratory } \\
\text { level } \\
\text { (Industrial } \\
\text { level while } \\
\text { extracting } \\
\text { metals like } \\
(\mathrm{Ni}, \mathrm{V}, \mathrm{Mo} \text {, } \\
\text { etc) }\end{array}$ & $43-46$ \\
\hline $\begin{array}{l}\mathrm{Pt}, \mathrm{Pd}, \mathrm{Rh} / \text { carbon } \\
\mathrm{Pt}-1.3 \% \\
\mathrm{Pd}-0.8 \% \\
\mathrm{Rh}-0.973 \% \\
\mathrm{C}-\text { rest of the } \% \\
\text { with respect to } \\
\text { the PGM }\end{array}$ & $\begin{array}{l}\text { Supercritical } \\
\text { fluids } \\
\text { oxidation }\end{array}$ & $\begin{array}{l}\text { Low operating } \\
\text { temperature }\end{array}$ & $\begin{array}{l}\text { The high } \mathrm{Pd} \\
\text { recovery rate }\end{array}$ & $\begin{array}{l}\text { +High recovery } \\
\text { efficiency (only Pd), } \\
\text { +low investment and } \\
\text { cost } \\
\text {-Low Pt and Rh } \\
\text { recovery, } \\
\text {-immature } \\
\text { technology, }\end{array}$ & $\begin{array}{l}\text { Waste gas and } \\
\text { waste oil pollution }\end{array}$ & $\begin{array}{l}\text { Pd: } 96 \%, \\
\text { Pt: } 95 \% \\
\text { Rh:95\% }\end{array}$ & $\begin{array}{l}\text { Laboratory } \\
\text { level }\end{array}$ & $47-52$ \\
\hline $\begin{array}{l}\text { Pt,Pd/Al } \\
\text { Pt- } 0.15 \% \\
\text { Pd- } 0.07 \% \\
\text { Pb- } 1.56 \% \\
\text { Al- } 98.21 \%\end{array}$ & $\begin{array}{l}\text { Supported } \\
\text { liquid } \\
\text { membrane }\end{array}$ & $\begin{array}{l}\text { High operating } \\
\text { temperature }\end{array}$ & $\begin{array}{l}\text { High } \\
\text { selectivity }\end{array}$ & $\begin{array}{l}\text { +High selectivity } \\
\text {-Low extraction rate } \\
\text {-High wastes }\end{array}$ & wastes & $\begin{array}{l}\text { No } \\
\text { reliable } \\
\text { data } \\
\text { available }\end{array}$ & $\begin{array}{l}\text { Laboratory } \\
\text { level }\end{array}$ & $53-58$ \\
\hline $\begin{array}{l}\text { Pt,Rh/slug } \\
\text { Pt- } 0.23 \% \\
\text { Rh- } 0.053 \% \\
\text { Ce- } 6.153 \% \\
\text { Zr- } 1.437 \% \\
\text { Ba- } 1.15 \% \\
\text { Mg- } 5.893 \% \\
\text { Al- } 20.27 \% \\
\text { O- } 64.814 \%\end{array}$ & $\begin{array}{l}\text { Pyrometallurgi } \\
\text { cal process }\end{array}$ & $\begin{array}{l}\text { High operating } \\
\text { temperature }(750 \\
\left.-1500^{\circ} \mathrm{C}\right)\end{array}$ & $\begin{array}{l}\text { High } \mathrm{Pt}, \mathrm{Pd} \\
\text { and } \mathrm{Rh} \\
\text { recovery rate }\end{array}$ & $\begin{array}{l}\text { +High recovery } \\
\text { efficiency, } \\
\text { +Mature technology, } \\
\text {-high investment, } \\
\text {-high energy } \\
\text { consumption }\end{array}$ & $\begin{array}{l}\text { Large volumes of } \\
\text { slags and air } \\
\text { pollution }\end{array}$ & $\begin{array}{l}\text { Pd: } 98 \%, \\
\text { Pt: } 98 \% \\
\text { Rh: } 97 \%\end{array}$ & $\begin{array}{l}\text { Industrial } \\
\text { level }\end{array}$ & $59-78$ \\
\hline $\begin{array}{l}\mathrm{Pt}, \mathrm{Pd}, \mathrm{Rh} / \\
\mathrm{Mg}_{2} \mathrm{Al}_{4} \mathrm{Si}_{5} \mathrm{O}_{18} \\
\mathrm{Pt}-0.0056 \% \\
\mathrm{Pd}-0.0062 \% \\
\mathrm{Rh}-0.0019 \% \\
\mathrm{Al}_{2} \mathrm{O}_{3}-42.0 \% \\
\mathrm{SiO}_{2}-32.9 \% \\
\mathrm{MgO}-8.2 \%\end{array}$ & $\begin{array}{l}\text { Separation } \\
\text { process } \\
\text { (magnetic) }\end{array}$ & $\begin{array}{l}\text { High operating } \\
\text { temperature }(800 \\
\left.-1300{ }^{\circ} \mathrm{C}\right) \text {, low } \\
\text { pollutants }\end{array}$ & $\begin{array}{l}\text { Moderate } \mathrm{Pt}, \\
\mathrm{Pd} \text { and } \mathrm{Rh} \\
\text { recovery rate } \\
\text { (experimental } \\
\text { stage) }\end{array}$ & $\begin{array}{l}\text { +Moderate recovery } \\
\text { efficiency, } \\
\text { +low investment, } \\
\text { +low energy } \\
\text { consumption } \\
\text {-immature } \\
\text { technology }\end{array}$ & $\begin{array}{l}\text { Environmentally } \\
\text { friendly, negligible } \\
\mathrm{Cl}_{2} \text { emission }\end{array}$ & $\begin{array}{l}\text { No } \\
\text { reliable } \\
\text { data } \\
\text { available }\end{array}$ & $\begin{array}{l}\text { Laboratory } \\
\text { level }\end{array}$ & $80-85$ \\
\hline $\begin{array}{l}\mathrm{Pd} / \mathrm{Al} \text { base metal } \\
\mathrm{Pd}-1.2 \% \\
\mathrm{Al}-98.80 \%\end{array}$ & $\begin{array}{l}\text { Two-steps } \\
\text { electrochemica } \\
1 \text { process in } \\
\text { molten salts }\end{array}$ & $\begin{array}{l}\text { High operating } \\
\text { temperature } \\
\left(950-970{ }^{\circ} \mathrm{C}\right), \\
\text { emission of } \\
\text { greenhouse } \\
\text { gases }\end{array}$ & $\begin{array}{l}\text { The } \\
\text { concentration } \\
\text { of metals in } \mathrm{Al} \\
\text { alloy }\end{array}$ & $\begin{array}{l}\text { +High recovery } \\
\text { efficiency } \\
- \text { Two steps }\end{array}$ & $\begin{array}{l}\text { Greenhouse gasses } \\
\text { emission }\end{array}$ & $\begin{array}{l}\text { Pd: } 98- \\
99 \%\end{array}$ & $\begin{array}{l}\text { Laboratory } \\
\text { level }\end{array}$ & $86-88$ \\
\hline $\begin{array}{l}\mathrm{Pt}(+\mathrm{Re}) / \gamma \mathrm{Al}_{2} \mathrm{O}_{3} \\
\mathrm{Pt}-0.35 \% \\
\mathrm{Re}-0.2 \% \\
\mathrm{Al}_{2} \mathrm{O}_{3}-99.45 \%\end{array}$ & $\begin{array}{l}\text { One-step } \\
\text { electrochemica } \\
1 \text { process in } \\
\text { molten salts }\end{array}$ & $\begin{array}{l}\text { High operating } \\
\text { temperature } \\
\left(700-850^{\circ} \mathrm{C}\right)\end{array}$ & $\begin{array}{l}\text { The } \\
\text { concentration } \\
\text { of metals in } \mathrm{Al} \\
\text { alloy }\end{array}$ & $\begin{array}{l}\text { +High recovery } \\
\text { efficiency } \\
+ \text { Low waste } \\
\text { emission } \\
+ \text { Co-production of } \\
\text { high-purity } \\
\text { aluminum } \\
+\mathrm{O}_{2} \text { production } \\
\text { - Under study }\end{array}$ & Under study & $\begin{array}{l}\text { Under } \\
\text { study }\end{array}$ & $\begin{array}{l}\text { Laboratory } \\
\text { level }\end{array}$ & 92 \\
\hline
\end{tabular}

663 Note: Generic composition of the feed mentioned in this table is only for one particular study with a high recovery 664 rate, the composition varies with studies and can be found in the references mentioned.

The methods can be united into several groups according to the diagram presented in the

667 figure. 12; however this classification is rather suppositive as combined approaches are often 668 used in practice. 


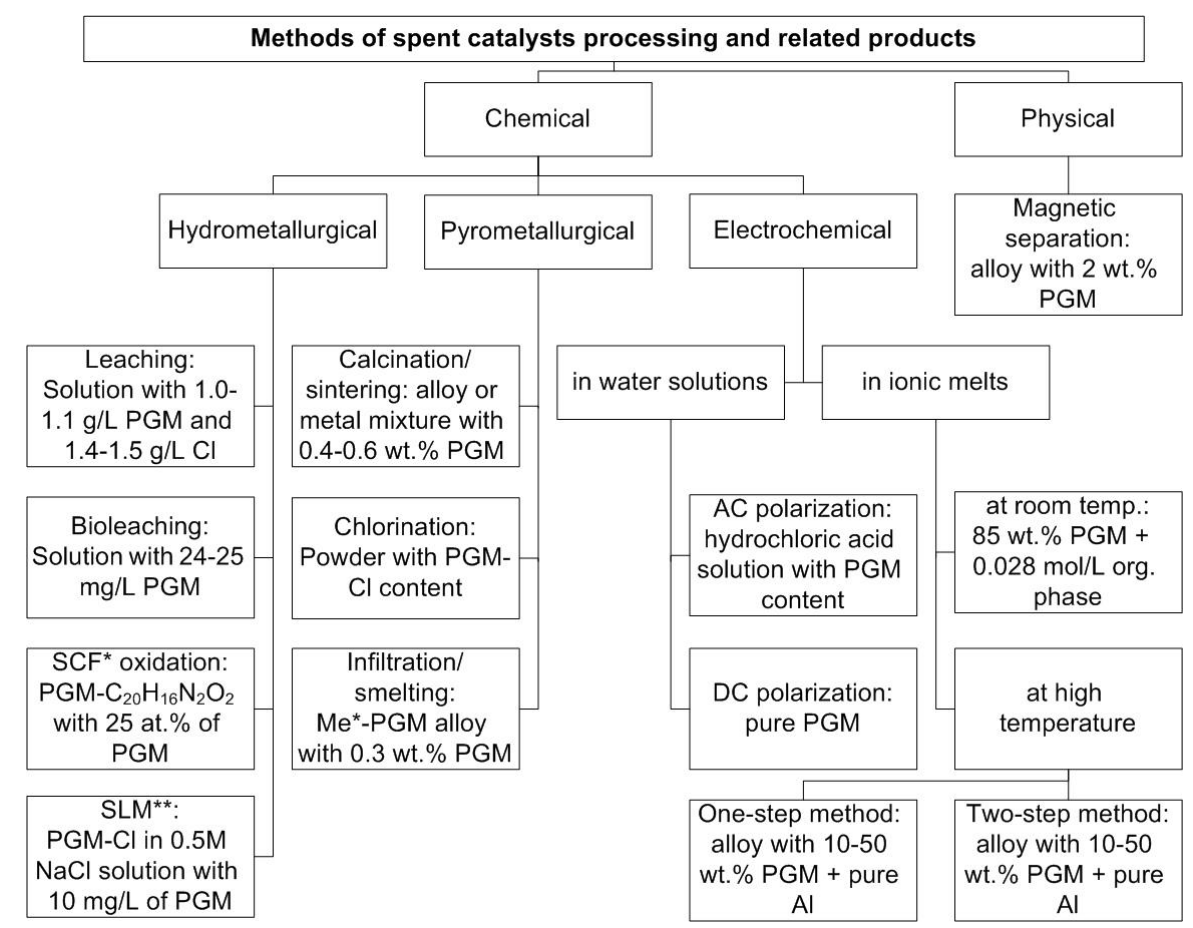

Figure 12. Variety of techniques used for spent catalysts processing and related products (Note: *SCF supercritical fluid; $\mathrm{Me}^{*}=\mathrm{Fe}, \mathrm{Cu}, \mathrm{Pb}, \mathrm{Al} ; \mathrm{SLM}$ - supported liquid membrane) [94-101].

The comparison shows that among the huge variety of technologies several have prospects of further development. Different products of the processes require appropriate treatment to extract valuable metals and purify them. Common significant drawbacks of the methods often are the high cost of equipment and consumables, the high specific energy consumption, and the huge amount of waste.

\section{Separation process}

In this process, individual PGMs, which are in their chlorocomplex form are separated from the leaching solution. Solvent extraction, ion exchange, and precipitation methods are usually implemented, where the extractants are added to the synthetic solution for individual PGMs separation. Extractants, ion exchange resins, and precipitants play a vital role in the separation behavior of Pt and Pd metals. In this section, the three separation methods mentioned above will be discussed in brief along with the effects of extractants/ion exchange resin/precipitants on the separation behavior of PGMs from the leach liquor. (Note: these separation methods are only used in hydrometallurgical processes)

\subsection{Solvent extraction (SX) method}

In the SX method, extractants are added to the pretreated leaching liquor where ideal concentrations of PGMs are available for the separation. Three types of extractants added according to the requirements are namely, basic (amine), neutral, and acidic extractants. According to the literature study conducted in Nguyen et al. [102], Pt and Pd can be completely extracted by selective stripping from the leaching solution by using amines, although complications with the formation of the third phase and difficulties in stripping leading to the compulsion in adjusting the stripping solution might occur. By using neutral extractants, selective extraction of Pd

Table 3. Summary of the advantages and disadvantages of extractants in the separation and extraction of $\mathrm{Pt}$ and $\mathrm{Pd}$ in chloride leaching (adopted from [102]).

\begin{tabular}{|c|c|c|cc|c|}
\hline Extractants & Aqueous & Advantage & Disadvantage & Ref. \\
\hline Alamine $300^{\mathrm{a}}$ & $0.01 \mathrm{M} \mathrm{Pt}$ and Pd & Individual extraction of Pt over Pd & Critical & stripping & issues. \\
\hline
\end{tabular}




\begin{tabular}{|c|c|c|c|c|}
\hline & & $\begin{array}{l}\text { while using saturated } \mathrm{NaCl} \text { solution at } \\
\text { pH } 1.5\end{array}$ & extraction of $\mathrm{Pd}$ & \\
\hline \multirow[t]{2}{*}{ Alamine $336^{\mathrm{a}}$} & $0.0001 \mathrm{M} \mathrm{Pt}$ and Pd & $\begin{array}{l}\text { Simultaneous extraction of } \mathrm{Pt} \text { and } \mathrm{Pd} \\
\text { from the } 1-5 \mathrm{M} \mathrm{HCl} \text {. }\end{array}$ & High co-stripping of Pt along with Pd & 105 \\
\hline & $\mathrm{Pt}, \mathrm{Pd}$ & $\begin{array}{l}\text { Extraction of both } \mathrm{Pt} \text { and } \mathrm{Pd} \text { from } \mathrm{HCl} \\
\text { with } 15 \% \mathrm{w} / \mathrm{w} \text { concentration }\end{array}$ & $\begin{array}{l}\text { No data on Pt and Pd separation from } \\
\text { stripping }\end{array}$ & 106 \\
\hline $\mathrm{TIOA}^{\mathrm{a}}$ & $\mathrm{Pt}, \mathrm{Pd}, \mathrm{Ru}, \mathrm{Ir}, \mathrm{Au}$ & $\begin{array}{l}\text { Extraction of } \mathrm{Pt}, \mathrm{Pd} \text {, and } \mathrm{Au} \text { over } \mathrm{Pu} \\
\text { and Ir from } 3.5-6 \mathrm{M} \mathrm{HCl} \text {. }\end{array}$ & $\begin{array}{l}\text { No data on Pt and Pd separation from } \\
\text { stripping }\end{array}$ & 107 \\
\hline DMDCHTDGA $^{\mathrm{b}}$ & $0.1 \mathrm{~g} / \mathrm{L} \mathrm{Pt}, \mathrm{Pd}$ & $\begin{array}{l}\mathrm{Pd} \text { and } \mathrm{Pt} \text { co-extraction at } 8 \mathrm{M} \mathrm{HCl} \mathrm{Pd} \\
\text { and } \mathrm{Pt} \text { separation using the stripping } \\
\text { step. }\end{array}$ & $\begin{array}{l}\text { Extraction is synthesized. separation } \\
\text { efficiency is low }\end{array}$ & 108 \\
\hline $\mathrm{DBSO}^{\mathrm{b}}$ & $1000 \mathrm{~g} / \mathrm{L} \mathrm{Pt}, \mathrm{Pd}$ & Pd extraction over Pt at $0.1 \mathrm{M} \mathrm{HCl}$ & $\begin{array}{l}\text { Extraction is synthesized. Usage of } 5 \\
\mathrm{M} \text { ammonia solution }+3 \% \mathrm{v} / \mathrm{v} \mathrm{NH} \mathrm{H}_{4} \mathrm{Cl} \\
\text { for metal stripping. }\end{array}$ & 109 \\
\hline Cyanex $923^{\mathrm{b}}$ & $50 \mathrm{mM}$ of $\mathrm{Pd}$ and $\mathrm{Pt}$ & Pt extraction over Pd at $5 \mathrm{M} \mathrm{HCl}$ & $\begin{array}{l}\text { The low separation efficiency of } \mathrm{Pd} \\
\text { and } \mathrm{Pt}\end{array}$ & 110 \\
\hline Cyphos IL 101/104 & $\begin{array}{l}2.5 \mathrm{mM} \text { of } \mathrm{Pd}, \mathrm{Pt}, \mathrm{Ni} \\
\mathrm{Cu}, \mathrm{Ir}, \mathrm{Pb}, \mathrm{Ir}, \mathrm{Ru}, \mathrm{Rh}\end{array}$ & $\begin{array}{l}\text { Pd extraction over other metals at } 0.1 \mathrm{M} \\
\mathrm{HCl}\end{array}$ & $\begin{array}{l}\text { The low separation efficiency of Pd } \\
\text { and } \mathrm{Pt}\end{array}$ & 111 \\
\hline $\mathrm{TBP}^{\mathrm{b}}$ & $\begin{array}{l}\text { Pt-0.55, Pd-0.15, Cr- } \\
0.1, \mathrm{Mn}-0.5, \mathrm{Ni}-1, \mathrm{Fe}- \\
1.5 \mathrm{~g} / \mathrm{L}\end{array}$ & $\begin{array}{l}\text { Pd extraction over other metals at } 3 \mathrm{M} \\
\mathrm{HCl}\end{array}$ & Loss of Pt from Fe precipitation & 112 \\
\hline $\mathrm{PC} 88 \mathrm{~A}^{\mathrm{c}}$ & $0.001 \mathrm{~g} / \mathrm{L} \mathrm{Pt}, \mathrm{Pd}$ & $\begin{array}{l}\text { Extraction of } \mathrm{Pd} \text { over Pt from } 1 \mathrm{M} \mathrm{HCl} \\
+1 \mathrm{M} \mathrm{HClO}_{4} \text { solution }\end{array}$ & $\begin{array}{l}\text { Low metal concentration and low } \\
\mathrm{HCl} \text { concentration in the leaching } \\
\text { solution }\end{array}$ & 113 \\
\hline $\mathrm{N} 530^{\mathrm{c}}$ & $\begin{array}{l}\text { Pt-10.23, Pd-5.95, } \\
\text { Au- } 5.42 \text { g/L }\end{array}$ & $\begin{array}{l}\text { Extraction of } \mathrm{Au} \text { over } \mathrm{Pt} \text { in } 5 \mathrm{M} \mathrm{HCl} \text {. } \\
\text { Extraction of } \mathrm{Pd} \text { over } \mathrm{Au} \text { and } \mathrm{Pt} \text { in } \mathrm{HCl} \\
\text { solution of } \mathrm{pH} 2.0\end{array}$ & $\begin{array}{l}\text { Pd stripping only possible at high } \mathrm{HCl} \\
\text { concentration }(6 \mathrm{M})\end{array}$ & 114 \\
\hline LIX $63^{\mathrm{c}}$ & $\begin{array}{l}100 \mathrm{ppm} \text { of } \mathrm{Pd}(\mathrm{II}) \\
\mathrm{Pt}(\mathrm{IV}), \mathrm{Ir}(\mathrm{IV}) \text { and } \\
\mathrm{Rh}(\mathrm{III}), 6 \mathrm{M} \mathrm{HCl}\end{array}$ & $\begin{array}{l}\text { Individual Pd extraction over other } \\
\text { metals, easily desorbed by using } 0.5 \mathrm{M} \\
\left(\mathrm{NH}_{2}\right)_{2} \mathrm{CS} \text { stripping reagent }\end{array}$ & $\begin{array}{l}\text { Coextraction of other PGMs occurs at } \\
\text { high LIX } 63 \text { concentrations (over } 0.2 \\
\text { M) }\end{array}$ & 115 \\
\hline \multirow[t]{2}{*}{ LIX 84I } & $\begin{array}{l}\text { Pt-0.55, Pd-0.15, Cr- } \\
0.1, \mathrm{Mn}-0.5, \mathrm{Ni}-1, \mathrm{Fe}- \\
1.5 \mathrm{~g} / \mathrm{L}\end{array}$ & $\begin{array}{l}\text { Extraction of Pd over other metals at } 3 \\
\mathrm{M} \mathrm{HCl} \text {. }\end{array}$ & Co-extraction of $\mathrm{Fe}$ is high & 116 \\
\hline & $1 \mathrm{~g} / \mathrm{L} \mathrm{Pt}, \mathrm{Pd}$ & $\begin{array}{l}\text { Individual extraction of } \mathrm{Pd} \text { over other } \\
\text { metals from the solution with } \mathrm{pH} \text { values } \\
1-3 \text {, Separation factor }=400\end{array}$ & $\begin{array}{l}\text { Metal stripping from } 6 \mathrm{M} \mathrm{HCl} \text {, low } \\
\mathrm{HCl} \text { concentration in the leaching } \\
\text { solution. }\end{array}$ & 117 \\
\hline
\end{tabular}

\section{Note: a-Basic extractants, b-Neutral extractants, c-Acidic extractants}

702 Alamine $300=$ tri-n-octyl amine; Alamine $336=$ tri-octyl/ dodecyl amine; TIOA = tri-iso-octylamine; 703 DMDCHTDGA = N,N'-dimethyl-N,N'-dicyclohexylthiodiglycolamide; DBSO = dibutyl sulfoxide; Cyanex $932=$ 704 the phosphine oxides; Cyphos1IL 104 = trihexyl(tetradecyl)phosphonium bis-2,4,4-trimethylpentylphosphinate; 705 Cyphos IL 101 = trihexyl(tetradecyl)phosphonium chloride; TBP = tributyl phosphate; PC-88A = 2-ethylhexyl 706 phosphonic acid mono-2-ethylhexyl ester; N530 = 2-hydroxy-4-sec-octanoyl diphenyl-ketoxime; LIX $63=5,8$ 707 diethyl-7-hydroxydodecane-6-oximeLIX 84I = 2-hydroxy-5-nonylacetophenone oxime.

The separation behavior of $\mathrm{Pt}(\mathrm{IV})$ and $\mathrm{Ir}(\mathrm{III})$ in three different leaching solutions

\subsection{Ion-exchange method}


In the ion-exchange method, the ion exchange resin is added to the leaching solution, sometimes combined with the synthetic solution loaded with PGMs in their complex form. Ionexchangers play a vital role in the separation process and some of the details on the ionexchangers are mentioned in table 4. The PGMs are adsorbed on the resin surface. The elution process is carried out on loaded organic resins by adding eluents like $\mathrm{Na}_{2} \mathrm{CO}_{3}, \mathrm{NaCl}$, and a mixture of thiourea and $\mathrm{HCl}$ to strip the PGMs. Separation of $\mathrm{Pt}$ and $\mathrm{Rh}$ from the $\mathrm{HCl}$ solution with varying concentrations of 0.1-5 M using IX technique was investigated in [119]. Three different ion exchangers were used namely AGMP-1, AG1-x2, and AG1-x8. The adsorption phenomena of $\mathrm{Pt}$ and $\mathrm{Rh}$ were similar in all the anion exchangers. Pt showed better adsorption percentage even at $5 \mathrm{M} \mathrm{HCl}$ solution while the percentage was less than $20 \%$ in the case of $\mathrm{Rh}$ throughout 0.1 to $5 \mathrm{M}$ concentration. It is worth noting that an increase in the concentration of exchangers in the solution increased the adsorption percentage of both $\mathrm{Pt}$ and $\mathrm{Rh}$. Langmuir isotherm was followed by resins for $\mathrm{Pt}$ adsorption. The adsorption percentage of $\mathrm{Rh}$ increases with an increase in the $\mathrm{HCl}$ concentration, while the percentage of Pt decreases. AG1-x8 was a better exchanger compared to the other two, as AG1-x8 had better Pt loading capacity and also a high separation factor between $\mathrm{Rh}$ and $\mathrm{Pt}$. Further continuous column experiment showed that $\mathrm{Pt}$ and $\mathrm{Rh}$ can be completely separated using $0.1 \mathrm{HCl}$ solution mixture. $\mathrm{Na}_{2} \mathrm{CO}_{3}, \mathrm{NaCl}$, and a mixture of thiourea and $\mathrm{HCl}$ were used as eluting agents, and thiourea was more effective in eluting Pt from the loaded organic resin. The process is effective and can be adapted to the commercial level. The resin used in this process can be regenerated after the desorption of the PGMs.

In [120], the separation behavior of $\mathrm{Pt}, \mathrm{Pd}$, and $\mathrm{Rh}$ in $2.35 \mathrm{M} \mathrm{HCl}$ solution was investigated where ion exchanger resins namely XUS 43600 (thiouronium functional group), Lewatit MonoPlus (M+) MP 600 (quaternary ammonium functional group), and Purolite S985 (polyamine functional group) were used. It was reported that Pt and Pd show high adsorption percentage in the XUS 43600 while Rh had poor adsorption behavior for all three resins. Sodium thiocyanate $(2 \mathrm{~mol} / \mathrm{L})$, thiourea $(1 \mathrm{~mol} / \mathrm{L})$ in sodium hydroxide $(2 \mathrm{~mol} / \mathrm{L})$ thiourea $(1 \mathrm{~mol} / \mathrm{L})$ in hydrochloric acid $(2 \mathrm{~mol} / \mathrm{L})$, and hydrochloric acid $(2 \mathrm{~mol} / \mathrm{L})$ were used as an eluting agent. Desorption of Pt, Pd from the loaded resins was better using acidic thiourea. In both [119] and [120], it is stated that the adsorption of $\mathrm{Rh}$ on the resins and desorption from the loaded resins using the eluting agent were difficult. Alternative methods need to be used for the recovery of Rh.

Table 4. Summary of the advantages and disadvantages of ion-exchangers in the separation and extraction of $\mathrm{Pt}, \mathrm{Pd}$, and $\mathrm{Rh}$ in chloride leaching

\begin{tabular}{|c|c|c|c|c|}
\hline Ion exchanger & Aqueous & Advantages & Disadvantages & Ref. \\
\hline AG1-x2 & $\begin{array}{l}0.001 \mathrm{M} \mathrm{Pt}, 0.001 \mathrm{Rh}, 0.1 \\
\text { to } 5 \mathrm{M} \mathrm{HCl}\end{array}$ & $\begin{array}{l}\text { High Pt adsorption at } 0.1 \mathrm{M} \\
\mathrm{HCl}\end{array}$ & \begin{tabular}{lll} 
Poor Rh & \multicolumn{2}{c}{ adsorption } \\
percentage at & all & HCl \\
concentrations & &
\end{tabular} & 119 \\
\hline AG1-x8 & $\begin{array}{l}0.001 \mathrm{M} \mathrm{Pt}, 0.001 \mathrm{Rh}, 0.1 \\
\text { to } 5 \mathrm{M} \mathrm{HCl}\end{array}$ & $\begin{array}{l}\text { High Pt and Rh loading } \\
\text { capacity, selectivity between } \\
\text { (large separation factor) Pt } \\
\text { and Rh }\end{array}$ & $\begin{array}{l}\text { Requires high } \mathrm{HCl}(5 \mathrm{M}) \\
\text { and high resin }(20 \mathrm{~g} / \mathrm{L}) \\
\text { concentrations separate } \mathrm{Rh}\end{array}$ & 119 \\
\hline AGMP-1 & $\begin{array}{l}0.001 \mathrm{M} \mathrm{Pt}, 0.001 \mathrm{Rh}, 0.1 \\
\text { to } 5 \mathrm{M} \mathrm{HCl}\end{array}$ & 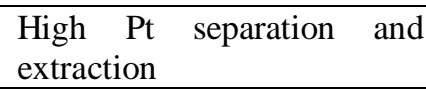 & $\begin{array}{lccc}\text { low } & \mathrm{Rh} & \text { separation } & \text { and } \\
\text { extraction } & & & \\
\end{array}$ & 119 \\
\hline XUS 43600 & $\begin{array}{l}\text { Leaching solution } \\
(0.000129 \mathrm{M} \mathrm{Pt} \text {, } \\
0.000125 \mathrm{M} \mathrm{Pd}, \\
0.000033 \mathrm{M} \mathrm{Rh}, 2.35 \\
\mathrm{M} \mathrm{HCl}) \text {, synthetic } \\
\text { solution(, } 0.000513 \\
\mathrm{M} \mathrm{Pt}, 0.000470 \mathrm{M} \\
\mathrm{Pd} \text {, and } 0.000194 \mathrm{M} \\
\mathrm{Rh}, 4.11 \mathrm{M} \mathrm{HCl})\end{array}$ & $\begin{array}{l}\text { High Pt and Pd extraction } \\
\text { from both the solution type } \\
\text { of around } 99.9 \%\end{array}$ & $\begin{array}{lccc}\text { low } & \text { Rh } & \text { final } & \text { elution } \\
\text { percentage } & & \\
\end{array}$ & 120 \\
\hline $\begin{array}{ll}\text { Lewatit } & (\mathrm{M}+) \\
\text { MP 600 } & \\
\end{array}$ & $\begin{array}{l}\text { Leaching solution } \\
(0.000129 \mathrm{M} \mathrm{Pt} \text {, }\end{array}$ & $\begin{array}{l}\text { High } \quad \text { Pd } \quad \begin{array}{r}\text { extraction } \\
\text { percentage and high elution }\end{array} \\
\end{array}$ & $\begin{array}{l}\text { Low Rh recovery and no } \\
\text { data on elution data }\end{array}$ & 120 \\
\hline
\end{tabular}




\begin{tabular}{|c|c|c|c|c|}
\hline & $\begin{array}{l}0.000125 \mathrm{M} \mathrm{Pd}, \\
0.000033 \mathrm{M} \mathrm{Rh}, 2.35 \\
\mathrm{M} \mathrm{HCl}), \text { synthetic } \\
\text { solution(, } 0.000513 \\
\mathrm{M} \mathrm{Pt}, 0.000470 \mathrm{M} \\
\mathrm{Pd} \text {, and } 0.000194 \mathrm{M} \\
\mathrm{Rh}, 4.11 \mathrm{M} \mathrm{HCl})\end{array}$ & $\begin{array}{l}\text { percentage (using Thiourea } \\
1 \mathrm{M} \text { eluant in } \mathrm{HCl} 2 \mathrm{M} \text { ) }\end{array}$ & & \\
\hline Purolite S985 & $\begin{array}{l}\text { Leaching solution } \\
(0.000129 \mathrm{M} \mathrm{Pt}, \\
0.000125 \mathrm{M} \mathrm{Pd}, \\
0.000033 \mathrm{M} \mathrm{Rh}, 2.35 \\
\mathrm{M} \mathrm{HCl}), \text { synthetic } \\
\text { solution(, } 0.000513 \\
\mathrm{M} \mathrm{Pt}, 0.000470 \mathrm{M} \\
\mathrm{Pd}, \text { and } 0.000194 \mathrm{M} \\
\mathrm{Rh}, 4.11 \mathrm{M} \mathrm{HCl})\end{array}$ & $\begin{array}{l}\text { High Rh } r \text { recovery } \\
\text { percentage of } 87.8 \% \text { and } \\
94.8 \% \text { respectively from } \\
\text { leaching and synethetic } \\
\text { solution. }\end{array}$ & $\begin{array}{l}\text { Low Pd recovery and low } \\
\text { Rh final elution percentage }\end{array}$ & 120 \\
\hline Purolite S920 & $\begin{array}{l}0.150 \mathrm{~g} / \mathrm{L} \mathrm{Pd}, 109.5 \\
\mathrm{~g} / \mathrm{L} \mathrm{HCl}, 53.5 \mathrm{~g} / \mathrm{L} \\
\mathrm{NH}_{4} \mathrm{Cl}, 3.2 \mathrm{~g} / \mathrm{L} \\
\mathrm{Cu}(\mathrm{II}), 3.3 \mathrm{~g} / \mathrm{L} \mathrm{Zn}(\mathrm{II}), \\
2.8 \mathrm{~g} / \mathrm{L} \mathrm{Fe}(\mathrm{III}), 6 \mathrm{~g} / \mathrm{L} \\
\mathrm{Sn}(\mathrm{IV})\end{array}$ & $\begin{array}{l}\text { High Pd adsorption } \\
\text { percentage }\end{array}$ & No elution data & 121 \\
\hline Purolite S924 & $\begin{array}{l}0.150 \mathrm{~g} / \mathrm{L} \mathrm{Pd}, 109.5 \\
\mathrm{~g} / \mathrm{L} \mathrm{HCl}, 53.5 \mathrm{~g} / \mathrm{L} \\
\mathrm{NH}_{4} \mathrm{Cl}, 3.2 \mathrm{~g} / \mathrm{L} \\
\mathrm{Cu}(\mathrm{II}), 3.3 \mathrm{~g} / \mathrm{L} \mathrm{Zn}(\mathrm{II}), \\
2.8 \mathrm{~g} / \mathrm{L} \mathrm{Fe}(\mathrm{III}), 6 \mathrm{~g} / \mathrm{L} \\
\mathrm{Sn}(\mathrm{IV})\end{array}$ & $\begin{array}{l}\text { No particular advantages } \\
\text { noted in Pd recovery } \\
\text { investiagtion }\end{array}$ & $\begin{array}{l}\text { Adsorption percentage of } \mathrm{Pd} \\
\text { less than } 65 \%\end{array}$ & 121 \\
\hline Lewatit TP-214, & $\begin{array}{l}0.0011 \mathrm{M} \mathrm{Pd}(\mathrm{II}), 0.1- \\
0.9 \mathrm{M} \mathrm{HCl}_{-0.9-0.1} \\
\mathrm{M} \mathrm{HNO}_{3}, 0.0011 \mathrm{M} \\
\mathrm{Pd}(\mathrm{II}), 1-2.0 \mathrm{M} \mathrm{HCl} \\
1.0 \mathrm{M} \mathrm{NaCl}\end{array}$ & High ion exchange rate & Difficulty in elution process & $\begin{array}{l}122, \\
123\end{array}$ \\
\hline
\end{tabular}

Note: AG 1- strongly basic anion exchangers with quaternary ammonium functional groups attached to the styrene divinylbenzene copolymer lattice, XUS 43600- Thiouronium (thiourea) attached to the Styrene-divinylbenzene, Lewatit (M+) MP 600- Quaternary ammonium (type 2) attached to the Styrene-divinylbenzene, Purolite S985Polyamine attached to the Polyacrylic-divinylbenzene, Purolite S920- thiourea functional group, Purolite S924- thiol functional group, Lewatit TP 214- thiourea or isothiourea functional group attached to Polystyrene-divinylbenzene

\subsection{Precipitation method}

In this method, a suitable precipitating agent is added to the leaching solution containing PGM ions, where the PGMs interact with the agents and form insoluble substances and are individually separated thereafter. The further step involves filtration where their pure metallic forms can be obtained. In [124], selective separation of $\mathrm{Rh}$ from the $\mathrm{HCl}$ solution containing $\mathrm{Pt}$ (IV), Pd (II), and Rh (III) ( $1 \mathrm{mmol} / \mathrm{L})$ metals was performed using the precipitation method. 4hexylaniline and 4-butylaniline were used as precipitants in high $\mathrm{HCl}$ concentrated solution for $\mathrm{Rh}$ separation. Centrifugation was used to separate the metal precipitates from the mixture. The findings showed that while using 4-hexylaniline precipitant, more than $90 \%$ of $\mathrm{Pt}$ and $\mathrm{Pd}$ were precipitated in 1-2 $\mathrm{M} \mathrm{HCl}$ concentration although a sudden decrease in the precipitation percentage with further increase in $\mathrm{HCl}$ concentration. In contrast to that, $85 \%$ of $\mathrm{Rh}$ was precipitated from the solution at high $\mathrm{HCl}$ concentrations (3-8 M). Using 4-butylaniline had poor precipitation percentage of $\mathrm{Pt}$ and $\mathrm{Pd}$ throughout the $(1-8 \mathrm{M}) \mathrm{HCl}$ concentration, while $\mathrm{Rh}$ was successfully precipitated with an increase in $\mathrm{HCl}$ concentration. The color of the $\mathrm{Rh}$ precipitate was pinkish, and unique ion-pair complex composed of $\left[\mathrm{RhCl}_{6}\right]^{3-} /$ chloride/anilinium ions in a 1:3:6 ratio was found. The process shows promising results for selective separation of $\mathrm{Rh}$ and authors claim that the process could influence the PGM recovery process at an industrial scale. 
High extraction of $\mathrm{Pt}$ from $\mathrm{HCl} / \mathrm{H}_{2} \mathrm{O}_{2}$ leach liquor $\left(9 \mathrm{M} \mathrm{HCl}\right.$ and 0.8 vol\% $\mathrm{H}_{2} \mathrm{O}_{2}$ ) was attained using precipitation technique in [125]. The suitable precipitation concentration of $\mathrm{Pt}$ species in the leaching solution is $0.2 \mathrm{~g} / \mathrm{L}$, which was attained by heating the solution at $190{ }^{\circ} \mathrm{C}$ to make the excess liquid evapourate. $\mathrm{NH}_{4} \mathrm{Cl}(290 \mathrm{~g} / \mathrm{L})$ was added to the solution with simultaneous stirring at $40{ }^{\circ} \mathrm{C}$. The yellowish $\mathrm{Pt}$ precipitate in a complex form of $\left(\mathrm{NH}_{4}\right)_{2}\left[\mathrm{PtCl}_{6}\right]$ was obtained. The later steps involved washing the precipitate with $\mathrm{NH}_{4} \mathrm{Cl}$ solution $(140 \mathrm{~g} / \mathrm{L})$ followed by the calcination. The Pt recovery rate was $96 \%$ and the purity was around $99.6 \%$. This method is simple, energy-efficient, and promising with no harmful gas emission.

\section{Industrial operations}

On an industrial level, many advancements and optimizations have been made in extracting the PGMs from spent catalysts. Commercial processes for the PGMs recovery from the spent catalyst and used electronic products have successfully been implemented by industries like Engelhard (USA), BASF (USA), Hereaus (Germany), Johnson Matthey (UK), Mitsubishi (Japan), Umicore (Belgium), Nippon (Japan). Table 5 shows the processes already in use commercially.

Table 5. Processes used for PGM recovery on a commercial scale [28, 126].

\begin{tabular}{|c|c|c|}
\hline Process & Specification & Industry \\
\hline ROSETM method & Pyrometallurgy & Nippon PGM Co. \\
\hline Melting method-1 & Pyrometallurgy & \\
\hline Metal Vapour Treatment & Pyrometallurgy & MatsudaSangyo Ltd \\
\hline The Plasma arc smelting process & Pyrometallurgy & $\begin{array}{l}\text { Texasgulf, USA and Safina, Czech } \\
\text { Republic }\end{array}$ \\
\hline Chlorination & Hydrometallurgy & Tanaka Kikinzoku \\
\hline Segregation & & N.E. ChemCat \\
\hline Aqua regia & Hydrometallurgy & \\
\hline $\mathrm{CN}$ extraction & Hydrometallurgy & US Bureau of Mining \\
\hline $\mathrm{HCl}$ leaching & Hydrometallurgy & Heraeus (Germany) \\
\hline
\end{tabular}

A new novel semi-industrial process combining pyrometallurgical treatment and electrolytic refining is been proposed by the Institute for Mining and Metallurgy Bor [127]. They claim that the process is economical, environmental, and highly efficient. A novel membrane electrode assemblies process has been developed by BASF catalysts LLC (USA) to eliminate the emission of highly toxic gas (HF) in the present recycling processes [128]. Cyanide leaching has been extensively used by the industries, although special attention needs to be given on the harmful byproducts released through this process. A novel three-liquid-phase extraction has shown promising results at the laboratory scale and can open a new path in developing an environmentally friendly extraction technique $[129,130]$. In a novel combination of pyro and hydrometallurgical process, the catalytic converter carrier and $\mathrm{Pt}-\mathrm{Cu}$ alloy samples acquired from the pyrometallurgical method were treated with aqua-regia (with and without fluoric acid). Solution and solid wastes were by-products of this process making it undesirable, although it has been stated that economical and environmental benefits can be excepted with an adequate combination of pyro and hydrometallurgical methods and can be adopted at commercial scale [131]. Biotechnological recovery where the metal ion-reducing bacterium (Shewanella algae) reduces and deposits the PGMs ions (Pt (IV), Pd (II), and Rh (III)) into metal nanoparticles at neutral $\mathrm{pH}$ and room temperature within $60 \mathrm{~min}$ using the electron donor formate was successfully developed by Saitoh et al. [132]. The adoption of this technology would be revolutionary and environmentally friendly. Currently, a lot of research is conducted to find the optimal way to recover the PGMs from the spent catalyst and a lot has been achieved at a laboratory scale. Some of them are transferable to the industrial level.

\section{Conclusion}


The platinum group metals are widely used in various industrial applications. The demand for the PGMs is inevitable because of its unique properties and the natural PGM resources are limited, which demands to recycle PGMs spent catalyst. The recycling process satisfies the demand and consumes the leftover catalysts in environmentally friendly way. This paper gives an overview of the processes used for the recycling of the spent catalyst. The processes are distinguished into hydrometallurgy, pyrometallurgy, physical magnetic separation, and electrochemical, which has advantages and disadvantages accordingly. While using the hydrometallurgical process, the by-products like toxic water wastes are released and recovery of $\mathrm{Rh}$ is poor when compared with the pyrometallurgical process. The bioleaching process is ecofriendly but the recovery efficiency of PGMs should be improved. The pyrometallurgical process needs huge energy and investments while the process is environmentally friendly compared to the hydrometallurgical process. The process can be economically beneficial when used in the large-scale industrial level. The physical magnetic separation process is relatively new and novel but promising results were attained, nonetheless, the process is still at its beginning stages. The new one-step electrometallurgical process with Pt recovery up to $99 \%$ was proposed by the authors of this paper. The process is still under study and major results are expected to be obtained soon. A lot of work has been done in different recycling processes and still, there is a scope of further improvement.

\section{Future scope}

Hydrometallurgical techniques are highly efficient for Pd extraction and get much more attention in comparison with other ones during recent years; however, Rh cannot be leached for more than $90 \%$. Strong solvents (aqua regia, cyanide, $\mathrm{H}_{2} \mathrm{SO}_{4}$, etc.) are used to dissolve the spent catalysts in the leaching process. The PGMs should be reduced to the metallic state before that. Cyanide leaching is a more efficient recovery process but it requires high temperatures, and cyanide is highly toxic. Pyrometallurgical techniques are well studied and applied in industry. The advantage is that calcination, chlorination, and PGM smelting collection (infiltration) can be performed at a higher rate compared to the hydrometallurgical processes. However, in the pyrometallurgical process, a high amount of energy is consumed. The emission of $\mathrm{SO}_{2}$ is also a significant drawback. Physical separation techniques are more simple, energy-efficient, and lowcost. It also eliminates the toxic gases usually released while using the hydro- and pyrometallurgical methods. Ni deposition on the PGMs is done by using an electroless-plating bath, complexing, and reducing agents. High-temperature electrochemical methods are much less studied. They are easy to set up, can be performed with low waste emission and with low energy and reactant consumption. However, they are not universal as they can only be applied for the $\gamma$ $\mathrm{Al}_{2} \mathrm{O}_{3}$-based catalysts. Complex cordierite-based (or similar) automotive exhaust gas converters can barely be successfully treated by the electrochemical process. Optimization of this technology is required for each of the oxide components. Nevertheless, the one-step electrochemical method appears to be a promising solution. However, it requires further research to be implemented on an industrial scale.

\section{Acknowledgments} 24122.

The reported study was funded by RFBR according to the research project № 18-29-

\section{References}

1. Richards, J.: Journal of Cleaner Production, 2006, vol. 14, pp. 324-333.

2. Mpinga, C.N., Eksteen, J.J., Aldrich, C., Dyer, L.: Minerals Engineering, 2015, vol. 78, pp. 93-113. 
3. Suoranta, T., Zugazua, O., Niemela, M., Peramaki, P.: Hydrometallurgy, 2015, vol. 154, pp. 56-62.

4. Marcilly, C.: Journal of Catalysis, 2003, vol. 216, pp. 47-62.

5. Kononova, O.N., Melnikov, A.M., Borisova, T.V.: Hydrometallurgy, 2012, vol. $117-$ 118, pp. 101-107.

6. Jewell, S., Kimball, S.M.: Mineral Commodity Summaries 2015. U.S. Geological Survey. Reston, Virginia: CreateSpace Independent Publishing Platform, 2015, vol. 196, pp. 120-121.

7. Xiao, Z., Laplante, A.R.: Minerals Engineering, 2004, vol. 17, pp. 961-979.

8. Fernandez, V.: International Review of Financial Analysis, 2017, vol. 52, pp. 333-347.

9. Safarzadeh, M.S., Horton, M., Van Rythoven, A.D.: Mineral Processing and Extractive Metallurgy Review, 2018, vol. 1, pp. 1-17.

10. Angelidis, T.N., Sklavounos, S.A.: Applied Catalysis A: General, 1995, vol. 1, pp. 121132.

11. Johnson Matthey, PGM Market Report February 2020.

12. Marafi, M., Stanislaus, A.: Resources Conservation and Recycling, 2008, vol. 6, pp. 859873.

13. Marafi, M., Stanislaus, A.: Resources Conservation and Recycling, 2008, vol. 1-2, pp. 126.

14. Marafi, M., Stanislaus, A.: Journal of Hazardous Materials, 2003, vol. 101, pp. 123-132.

15. Mishra, D., Kim, D.J., Ralph, D.E., Ahn, J.G., Rhee, Y.H.: Hydrometallurgy, 2007, vol. 88, pp. 202-209.

16. Deng, J., Ren, P., Deng, D., Yu, L., Yang, F., Bao, X.: Energy and Environmental Science, 2014, vol. 7, pp. 1919-1923.

17. Haigang, D., Jiachun, Z., Jialin, C., Yuedong, W., Bojie, L.: International Journal of Mineral Processing, 2015, vol. 145, pp. 108-113.

18. Zhang, L.G., Xu, Z.M.: Journal of Cleaner Production, 2016, vol. 127, pp. 19-36.

19. Akcil, A., Vegliò, F., Ferella, F., Okudan, M.D., Tuncuk, A.: Waste Management, 2015, vol. 45 , pp. $258-271$.

20. Hagelüken, C.: Chemistry Today, 2006, vol. 24, pp. 14-17.

21. Syed, S., "Silver recovery aqueous techniques from diverse sources: hydrometallurgy in recycling", Waste Management, 2016, vol. 50, pp. 234-256.

22. Işıldar, A., Rene, E.R., van Hullebusch, E.D., Lens, P.N.: Resources, Conservation \& Recycling, 2018, vol. 135, pp. 296-312.

23. Ghodrat, M., Rhamdhani, M.A., Brooks, G., Masood, S., Corder, G.: Journal of Cleaner Production, 2016, vol. 126, pp. 178-190.

24. Sun, P.P., Lee, M.S.: Hydrometallurgy, 2011, vol. 110, pp. 91-98.

25. Marinho, R.S., da Silva, C.N., Afonso, J.C., da Cunha, J.W.: Journal of Hazardous Materials, 2011, vol. 192, pp. 1155-1160.

26. Green, G., Smit, D.M.C., Maumela, H., Coetzer, G.: The Journal of The South African Institute of Mining and Metallurgy, 2004, vol. 104, pp. 323-331.

27. Angelidis, T.N., Skouraki, E.: Applied Catalysis A: General, 1996, vol. 142, pp. 387395.

28. Fornalczyk, A., Saternus, M.: Metalurgija, 2009, vol. 48, pp. 133-136.

29. Shams, K., Goodarzi, F.: Journal of Hazardous Materials, 2006, vol. B131, pp. 229-237.

30. Angelidis, T.N.: Topics in Catalysis, 2001, vol. 16-17, pp. 419-423.

31. Trinh, H.B., Lee, J., Srivastava, R.R., Kim, S.: Journal of Hazardous Materials, 2019, https://doi.org/10.1016/j.jhazmat.2019.120772 (In press)

32. Matjie, R.H., Scurrell, M.S., Bunt, J.: Materials Engineering, 2005, vol. 18, pp. 801-810.

33. Sarioğlan, S.: Platinum Metals Review, 2013, vol. 57, pp. 289-296.

34. Paiva, A.P., Ortet, O., Carvalho, G.I., Nogueira, C.A.: Hydrometallurgy, 2017, vol. 171, pp. 394-401. 
35. Kasuya, R., Miki, T., Morikawa, H., Tai, Y.: Minerals Engineering, 2016, vol. 87, pp. 25-31.

36. Spooren, J., Atia, T.A.,: Minerals Engineering, 2020, vol. 46, pp. 106153.

37. Firmansyah, M.L., Kubota, F., Yoshida, W., Goto, M.: Industrial and Engineering Chemistry Research, 2019, vol. 58, pp. 3845-3852.

38. Firmansyah, M.L., Kubota, F., Goto, M.: Journal of Chemical Engineering of Japan, 2019, vol. 52, pp. 835-842.

39. Atkinson G. B.: 1992. US Patent. 5160711.

40. Allen, R.J., Foller, P.C., Giallombardo, J.: 1992, U.S. Patent 5,102,632.

41. Chen, J., Huang, K.: Hydrometallurgy, 2006, vol. 82, pp. 164-171.

42. Shams, K., Beiggy, M.R., Shirazi, A.G.: Applied Catalysis A: General, 2004, vol. 258, pp. 227-234.

43. Zhuang, W.Q., Fitts, J.P., Ajo-Franklin, C.M., Maes, S., Alvarez-Cohen, L., Hennebel, T.: Current Opinion in Biotechnology, 2015, vol. 33, pp. 327-335.

44. Asghari, I., Mousavi, S.M., Amiri, F., Tavassoli, S.: Journal of Industrial and Engineering Chemistry, 2013, vol. 19, pp. 1069-1081.

45. Santhiya, D., Ting, Y.P.: Journal of Biotechnology, 2005, vol. 116, pp. 171-184.

46. Malekian, H., Salehi, M., Biria, D.: Waste Management, 2019, vol. 85, pp. 264-271.

47. Eckert, C.A., Knutson, B.L., Debenedetti, P.G.: Nature, 1996, vol. 383, pp. 313-318.

48. Phelps, C.L., Smart, N.G., Wai, C.M.: Journal of Chemical Education, 1996, vol. 73, pp. 1163-1168.

49. White, G.L., Lira, C.T.: Fluid Phase Equilibrium, 1992, vol. 78, pp. 269-284.

50. Vitu, S., Privat, R., Jaubert, J.N., \& Mutelet, F.: The Journal of Supercritical Fluids, 2008, vol. 45, pp. 1-26.

51. Faisal, M., Atsuta, Y., Daimon, H., Fujie, K.: Asia-Pacific Journal of Chemical Engineering”, 2008, vol. 3, pp. 364-367.

52. Collard, S., Gidner, A., Harrison, B., Stenmark, L.: 2006, U.S. Patent 7,122,167.

53. Danesi, P.R.: Sepaeparation Science and Technology, 1984, vol. 19, pp. 857-894.

54. Kemperman, A. J. B., Bargeman, D., Van Den Boomgaard, Th., Strathmann, H.: Separation Science and Technology, 1996, vol. 31, pp. 2733-2762.

55. de Gyves, J., San Miguel, R.E.: Industrial and Engineering Chemistry Research, 1999, vol. 38, pp. 2182-2202.

56. Fontas, C., Salvado, V., Hidalgo, M.: Industrial and Engineering Chemistry Research, 2002, vol. 41, pp.1616-1620.

57. Fontas, C., Salvado, V., Hidalgo, M.: Journal of Membrane Science, 2003, vol. 223, pp. 39-48.

58. Amini, M., Rahbar-Kelishami, A., Alipour, M., Vahidi, O.: Journal of Membrane Science and Research, 2018, vol. 4, pp. 121-135.

59. Jadhav, U.U., Hocheng, H.: Journal of Achievements in Materials and Manufacturing Engineering, 2012, vol. 54, pp. 159-167.

60. Parkinson, G., Ishio, S.: Chemical Engineering, 1987, vol. 94, pp. 25-31.

61. Havlik, T., Orac, D., Petranikova, M., Miskufova, A., Kukurugya, F., Takacova, Z.: Journal of Hazardous Materials, 2010, vol. 183, pp. 866-873.

62. Bronshtein, I., Feldman, Y., Shilstein, S., Wachtel, E., Lubomirsky, I., Kaplan, V.: Journal of Sustainable Metallurgy, 2018, vol. 4, pp. 103-114.

63. Kim, C.H., Woo, S.I., Jeon, S.H.: Industrial \& Engineering Chemistry Research, 2000, vol. 39, pp. 1185-1192.

64. Murray M.J.: 1962, US Patent, 3021209.

65. Horike, C., Morita, K., Okabe, T.H.: Metallurgical and Materials Transactions B, 2012, vol. 43, pp. 1300-1307.

66. Xu, S.Q., Xu, L.: China Nat. Res. Recycl. 1998, vol. 10, pp. 7-11. 
67. Kayanuma, Y., Okabe, T.H., Maeda, M.: Metallurgical and Materials Transactions B, 2004, vol. 35, pp. 817-824.

68. Benson,M., Bennett, C.R., Harry, J.E., Patel, M.K., Cross, M.: Resources, Conservation and Recycling, 2000, vol. 31, pp. 1-7.

69. Ezawa N.: 1993, US patent 5252305.

70. Hoffmann, J.E.: JOM, 1988, vol. 6, pp. 40-44.

71. Kolliopoulos, G., Balomenos, E., Giannopoulou, I., Yakoumis, I., Panias, D.: Open Access Library Journal, 2014, vol. 1, pp. e736.

72. Mishra, R.K., Reddy, R.G.: 10th International Precious Metals Institute, Florida, 1986, pp. 217-231.

73. He, X., Li, Y., Wu, X., Zhao, Y., Wang, H., Liu, W.: Precious Metals, 2016, vol. 37, pp. $1-5$.

74. Van Schalkwyk, R.J., Eksteen, J.J., Akdogan, G.: Hydrometallurgy, 2013, vol. 136, pp. 36-45.

75. Eksteen, J.J.: Minerals Engineering, 2011, vol. 24, pp. 676-687.

76. You, G., Fang, W., Li, Q., Ma, Y., Yang, X., Yang, H.: Metallurgical Analysis, 2016, vol. 36, pp. 7-11.

77. Zhang, L., Song Q., Liu, Y., Xu, Z.: Journal of Cleaner Production, 2019, vol. 239, 1180933.

78. Wei, X., Liu, C., Cao, H., Ning, P., Jin, W., Yang, Z., Wang, H., Sun, Z.: Journal of Cleaner Production, 2019, vol. 239, pp. 1180312.

79. Kirichenko, A.S., Seregin, A.N., Volkov, A.I.: Metallurgist, 2014, vol. 58, pp. 250-255.

80. Kim, W., Kim, B., Choi, D., Oki, T., Kim, S.: Journal of Hazardous Materials, 2010, vol. 183, pp. 29-34.

81. Liu, G., Ichinose, T., Tokumaru, A., Owada, S.: Materials Transactions, 2014, vol. 55, pp. 978-985.

82. Liu, G., Tokumaru, A., Owada, S.: Resources Processing, 2013, vol. 60, pp. 28-35.

83. Taninouchi, Y., Watanabe, T., Okabe, T.H.: Materials Transactions, 2017, vol. 58, pp. 410-419.

84. Taninouchi, Y., Okabe, T.H.: Materials Transactions, 2018, vol. 59, pp. 88-97.

85. Taninouchi, Y., Okabe, T.H.: Metallurgical and Materials Transactions B, 2018, vol. 49B, pp. 1781-1793.

86. Belov, S.F., Igumnov, M.S., Lovchinovsky, I.Yu. [In Russ]: Tsetnye metally, 1997, vol. 5, pp. 46-48.

87. Belov, S.F., Igumnov, M.S., Lovchinovsky, I.Yu. [In Russ]: Izvestiya VUZov. Tsvetnaya metallurgiya, 1985, vol. 4, pp. 63-67.

88. Belov, S.F., Igumnov, M.S., Lovchinovsky, I.Yu. [In Russ]: Tsvetnye metally, 1997, vol. 5, pp. 39-41.

89. Padamata, S.K.; Yasinskiy, A.S., Polyakov, P.V.: Metallurgical research \& technology, 2019, vol. 116, pp. 410.

90. Yasinskiy, A.S., Suzdaltsev, A.V., Polyakov, P.V. Padamata, S.K. Yushkova, O.V.: Ceramics International, 2020 vol. 46 (8) Part B, pp. 11539-11548.

91. Padamata, S.K., Yasinskiy, A.S., Polyakov, P.V.: New Journal of Chemistry, 2020 vol. 44, pp. 5152-5164.

92. Yasinskiy, A.S., Polyakov, P.V., Popov, Yu.N., Polyakov, A.A., Padamata, S.K.: 2018. RU Patent. 2689475.

93. Yasinskiy, A.S., Padamata, S.K., Polyakov, P.V., Varyukhin, D.Yu.: Non-ferrous metals, 2019, vol. 2, pp. 23-30.

94. Myrzabekov, B.E., Bayeshov, A.B., Makhanbetov, A.B., Mishra, B., Baigenzhenov, O.S.: Metallurgical and Materials Transactions B, 2018, 49, 23-27.

95. Giridhar, P., Venkatesan, K.A., Reddy, B.P., Srinivasan T. G., Vasudeva Rao, P. R.: Radiochimica Acta, 2006, 94, 131-136. 
96. Tumanova, N.Kh, Kochetova, S.A., Savchuk A.V.: ECS Transactions, 2009, 16 (49) 453459.

97. Leclerc, N., Legeai, S., Balva, M., Hazotte, C., Comel, J., Lapicque, F., Billy, E., Meux, E.: Metals, 2018, 8, 556.

98. Sharma, R., Gyergyek, S., Andersen, S.M.: ChemSusChem, 2018, 11, 3742-3750.

99. Song, Y., Tsuchida, Y., Matsumiya, M., Tsunashima, K.: Hydrometallurgy, 2018, 181, $164-168$.

100. Liu, C., Sun, S.C., Zhu, X.P., Tu, G.F., Zhang, J.Y.: IOP Conf. Ser.: Mater. Sci. Eng., 2019, 479012058.

101. Fornalczyk, A., Golak, S., Saternus, M.: Mathematical Problems in Engineering, 2013, Article ID 461085, https://doi.org/10.1155/2013/461085.

102. Nguyen, T.H., Sonu, C.H., Lee, M.S.: Journal of Industrial and Engineering Chemistry, 2015, vol. 32, pp. 238-245.

103. Paiva, P.A.: Davis B. et al. (eds), TMS 2018, 2018, pp. 2063-2073.

104. Swain, B., Jeong, J., Kim, S.K., Lee, J.C.: Hydrometallurgy, 2010, vol. 104, pp. $1-7$.

105. Sun, P.P., Lee, M.S.: Hydrometallurgy, 2011, vol. 109, pp. 181-184.

106. Yin, C.Y., Nikoloski, A.N., Wang, M.W.: Minerals Engineering, 2013, vol. 45, pp.18-21.

107. Mirza, M.Y.: Talania, 1980, vol. 27, pp. 101-106.

108. Paiva, A.P., Carvalho, G.I., Costa, M.C., Costa, A.M.R., Nogueira, C.: Solvent Extraction and Ion Exchnage, 2014, vol. 32, pp. 78-94.

109. Pan, L., Zhang, Z.: Minerals Engineering, 2009, vol. 22, pp. 1271-1276.

110. Gupta, B., Singh, I.: Hydrometallurgy, 2013, vol. 134, pp. 11-18.

111. Cieszynska, A., Wisniewski, M.: Separation and Purification Technology, 2011, vol. 80 , pp. $385-389$.

112. Lee, J.Y., Raju, B., Kumar, B.N., Kumar, J.R., Park, H.K., Reddy, B.R.: Separation and Purification Technology, 2010, vol. 73, pp. 213-218.

113. Bandekar, S.V., Dhadke, P.M.: Separation and Purification Technology, 1998, vol. 13, 129-135.

114. Shen, Y.F., Xue, W.Y.: Separation and Purification Technology, 2007, vol. 56. pp. 278-283.

115. Nguyen, T.H., Sonu, C.H., Lee, M.S.: Hydrometallurgy, 2016, vol. 164, pp. 7177.

116. Reddy, B.R., Raju, B., Lee, J.Y., Park, H.K.: Journal of Hazardous Materials, 2010, vol. 180, pp. 253-258.

117. Rane, M.V., Venugopal, V.: Hydrometallurgy, 2006, vol. 84, pp. 54-59.

118. Gupta, B., Singh, I., Mahandra, H.: Separation and Purification Technology, 2014, vol. 132, pp. 102-109.

119. Sun, P.P., Lee, J.Y., Lee, M.S.: Hydrometallurgy, 2012, vol. 113-114, pp. 200204.

120. Nikoloski, A.N., Ang, K., Li, D.: Hydrometallurgy, 2015, vol. 152, pp. 20-32.

121. Blokhin, A.A., Abovskii, N.D., Murashkin, Y.V.: Russian Journal of Applied Chemistry, 2007, vol. 80, pp. 1058-1062.

122. Hubicki, Z., Leszczyńska, M., Łodyga, B., Łodyga, A.: Desalination, 2007, vol. 207 (1-3), pp. 80-86.

123. Hubicki, Z., Wołowicz, A.: Journal of Hazardous Materials, 2009, vol.164, pp. 1414-1419.

124. Matsumoto, K., Yamakawa, S., Sezaki, Y., Katagiri, H., Jikei M.: ACS Omega, 2019, vol. 4, pp. 1868-1873.

125. Yousif, A.M.: Journal of Chemistry, 2019, vol. 2019, 2318157. 
126. Jha, M.K., Lee, J.C., Kim, M.S., Jeong. J., Kim, B.S., Kumar, V.: Hydrometallurgy, 2013, vol. 133, pp. 23-32.

127. Ivanović, S.Z., Trujuć, V.K., Gorgievski, M.D., Mišić, L.D., Božić, D.S.: 15th international research/expert conference "Trends in the development of machinery and associated technology", 2011, pp. 12-18.

128. Panda, R., Jha, M.K., Pathak, D.D.: Kim H. et al. (eds) Rare Metal Technology, TMS 2018, 2018, pp. 119-130.

129. Zhang, C., Huang, K., Yu, P., Liu, H.: Separation and Purification Technology, 2012, vol. 87, pp. 127-134.

130. Zhang, C., Huang, K., Yu, P., Liu, H.: Separation and Purification Technology, 2013, vol. 108, pp. 166-173.

131. Fornalczyk, A., Saternus, M.: Acta Metallurgica Sinica (English Letters), 2013, vol. 26, pp. 247-256.

132. Saitoh, N., Nomura, T., Konishi, Y.: Kim H. et al. (eds) Rare Metal Technology. TMS 2017, 2017, pp. 129-135

1098 